\title{
Low dosage of rimonabant leads to anxiolytic like behavior in a cannabinoid receptor independent manner via inhibiting expression levels and G-protein activity of kappa opioid receptors
}

Ferenc Zádor ${ }^{1}$, Nikolett Lénárt ${ }^{1}$, Balázs Csibrány ${ }^{1}$, Miklós Sántha ${ }^{1}$, Máté Molnár ${ }^{2}$, Bernadett Tuka ${ }^{2}$, Péter Klivényi ${ }^{2}$, László Vécsei ${ }^{2}$, Annamária Marton ${ }^{1}$, Csaba Vizler ${ }^{1}$, György M. Nagy ${ }^{3}$, Anna Borsodi $^{1}$, Sándor Benyhe ${ }^{1}$ and Eszter Páldy ${ }^{1 \dagger}$

${ }^{1}$ Institute of Biochemistry, Biological Research Centre, Hungarian Academy of Sciences, Temesvári krt. 62, H-6726 Szeged, Hungary

${ }^{2}$ MTA-SZTENeuroscience Research Group, University of Szeged, Semmelweis u. 6, H6725 Szeged, Hungary

${ }^{3}$ Department of Human Morphology and Developmental Biology, University of Semmelweis, Túzoltó u. 58, H-1094 Budapest, Hungary

${ }^{\dagger}$ Recent address: Pharmacology Institute, University of Heidelberg, Im Neuenheimer Feld 366, 69120 Heidelberg, Germany 


\section{ABSTRACT}

What is known: There is increasing number of studies demonstrating the direct effect of the cannabinoid receptor $1\left(\mathrm{CB}_{1}\right)$ antagonist / inverse agonist rimonabant on the opioid system; however they are mostly related to the mu opioid receptors (MOR). The dynorphin / kappa opioid receptor system is well known to mediate depression and anxiety like behavior. Clinical studies on chronic rimonabant administration have revealed that rimonabant leads to a very similar pathophysiology, suggesting a potential impact of rimonabant on the kappa opioid system.

Objectives: Our objectives were to examine the possible interactions between rimonabant and KOR in the ligand-receptor and receptor-G-protein level to follow the direct effect of rimonabant on KOR mediated signaling in vitro by using KOR cell lines and forebrain tissues of mice lacking either $\mathrm{CB}_{1}$ cannabinoid or both $\mathrm{CB}_{1}$ and $\mathrm{CB}_{2}$ cannabinoid receptors. Further on to better understand the clinical relevance of rimonabant on the KOR system we acutely treated mice with low dose of rimonabant and examined the KOR mediated G-protein activity and KOR protein expression levels of the forebrain tissues and also investigated the impact on depression- and anxiety-like behavior.

Results: Rimonabant in Chinese hamster ovary (CHO) cell membrane fractions stably transfected with rat KOR (CHO-rKOR) inhibited the KOR agonist $\left[{ }^{3} \mathrm{H}\right] \mathrm{U69593}$ specific binding in the micromolar range in radioligand competition binding experiments and specifically reduced KOR basal activity at the lower micromolar concentrations in $\left[{ }^{35} \mathrm{~S}\right] \mathrm{GTP} \gamma \mathrm{S}$ binding assays. In addition, rimonabant significantly inhibited KOR stimulation in micromolar range during dynorphin (1-11)-induced $\left[{ }^{35} \mathrm{~S}\right] \mathrm{GTP} \gamma \mathrm{S}$ binding experiments performed in $\mathrm{CHO}-\mathrm{rKOR}$ cell, $\mathrm{CB}_{1}$ single knockout $\left(\mathrm{CB}_{1}\right.$ K.O. $)$ and $\mathrm{CB}_{1} / \mathrm{CB}_{2}$ double knockout mouse forebrain membrane fractions. Our in vivo studies, by treating mice i.p. with a single dose of $0.1 \mathrm{mg} / \mathrm{kg}$ rimonabant, revealed that $24 \mathrm{~h}$ following the administration dynorphin (1-11)-induced KOR G-protein activity and the KOR expression levels were significantly reduced both in wild type and $\mathrm{CB}_{1}$ K.O. forebrain. Furthermore in elevated plus maze test the same treatment conditions showed an 
anxiolytic like effect of rimonabant that was reversed by administration of $1 \mathrm{mg} / \mathrm{kg}$ KOR antagonist norbinaltorphimine.

Conclusion: Rimonabant directly affects KOR function in micromolar concentrations in in vitro studies with a KOR specific inverse agonistic or antagonistic character. Our in vivo studies demonstrated that unlike upon chronic rimonabant administration which leads to undesired psychiatric dysfunctions, an acute low dose of rimonabant has an entirely opposite effect that is $\mathrm{CB}_{1}$ receptor independent. According to the information so far provided, this is the first report that links the impact of rimonabant on the KOR system at signaling, protein expression and behavioral level in such a pharmacological application. 


\section{ABBREVIATIONS}

$\mathrm{CB}_{1}$ : type 1 cannabinoid receptor

$\mathrm{CB}_{1} / \mathrm{CB}_{2}$ K.O.: $\mathrm{CB}_{1} / \mathrm{CB}_{2}$ double knock-out

$\mathrm{CB}_{2}$ : type 2 cannabinoid receptor

$\mathrm{CB}_{1}$ K.O.: $\mathrm{CB}_{1}$ knock-out

CHO: Chinese hamster ovary cell line

CHO-rKOR: Chinese hamster ovary cell line overexpressing rat $\kappa$-opioid receptor

DMSO: dimethyl sulfoxide

DOR: $\delta$-opioid receptor

DPDPE: [D-Pen ${ }^{2,5}$ ]-enkephalin hydrate

EGTA: ethyleneglycol-tetraacetic acid

EPM: elevated plus maze test

FST: forced swimming test

GAPDH: glycerine aldehyde phosphate dehydrogenase

GDP: guanosine 5'-diphosphate

GPCR: G-protein coupled receptor

GTP: guanosin 5'-triphosphate

GTP $\gamma$ S: Guanosine-5'-O-[ $\gamma$-thio] triphosphate

HRP: horseradish peroxidase

i.p.: intraperitoneal

KOR:K-opioid receptor

MOR: $\mu$-opioid receptor

Nor-BNI: norbinaltorphimine

rim.: rimonabant

S.E.M.: standard error of means

TEM: Tris- $\mathrm{HCl}$, EGTA, $\mathrm{MgCl}_{2}$

Tris-HCl: tris-(hydroxymethyl)-aminomethane hydrochloride

w.t.: wild type 


\section{INTRODUCTION}

Rimonabant (Rinaldi-Carmona et al., 1994), which reduces endogenous cannabinoid receptor 1 activity $\left(\mathrm{CB}_{1}\right)$, was the first appetite suppressant to be approved for medical use targeting $\mathrm{CB}_{1}$ receptors (Padwal and Majumdar, 2007). However because of its strong psychiatric side-effects, such as anxiety and depression, it was soon withdrawn from the market (Christensen et al., 2007). Several clinical (Christensen et al., 2007; Moreira and Crippa, 2009) and after the withdrawn preclinical studies (Beyer et al., 2010; Lockie et al., 2011) supported the psychiatric adverse effects of chronically administered rimonabant and frequently questioned its specificity at $\mathrm{CB}_{1}$ receptors (for review see Pertwee, 2010).

From many aspects the opioid and the cannabinoid system have a lot in common. Similarly to the cannabinoid antagonists, opioid antagonists, such as naloxone, have an impact on food intake and body weight as well (Yeomans and Gray, 1997), though have not been successful in antiobesity therapies (de Zwaan and Mitchell, 1992). Also, the endogenous opioid system plays an important role in the regulation of behavior and emotions. Activation mediated by the $\mu$ - and $\delta$-opioid receptors (MOR, DOR respectively) elevates mood (Filliol et al., 2000; Shippenberg et al., 2008), while signaling via the $\kappa$-opioid receptors (KOR) results in dysphoria and anxiety in humans (Pfeiffer et al., 1986; Wadenberg, 2003) and also in rodents (Bals-Kubik et al., 1993; Carlezon et al., 2009, 2006; Mague et al., 2003). KORs are widely expressed in brain areas which - in pathological conditions - are highly responsible for depression and anxiety disorders, including the hypothalamus, amygdala, locus coeruleus, nucleus accumbens (Beckstead et al., 1979; Schwarzer, 2009; Simon et al., 1979; Tanaka et al., 2000). These regions involve the dopaminergic, the serotonergic and the noradrenergic systems (Berger et al., 2006; Hurd, 1996; Mansour et al., 1995; Schwarzer, 2009) that are the primary targets for standard antidepressant drugs (Frazer, 1997; Millan, 2004). Thus it is not surprising that several studies came out confirming that KOR antagonists have antidepressant- and anxiolytic-like effects (Knoll et al., 2007; Mague et al., 2003; McLaughlin et al., 2003; Millan, 2004; Newton et al., 2002; Schwarzer, 2009; Wittmann et al., 2009, for review see Carlezon et al., 2009). Similarly, the $\mathrm{CB}_{1}$ cannabinoid 
receptors are widely expressed in brain areas that are directly coupled to process emotions, such as the prefrontal cortex, hippocampus, amygdala and hypothalamus (for review see Pertwee and Howlett, 2010).

Opioids and cannabinoids share a lot of similarities at the receptor level as well. Both cannabinoid and opioid receptors belong to the G-protein coupled receptor (GPCR) superfamily. They predominantly activate $\mathrm{G}_{\mathrm{i} / \mathrm{o}}$ inhibitory proteins, which leads to the inhibition of adenylyl cyclase activity resulting a decreased presynaptic neurotransmitter release (Bruchas et al., 2010; Demuth and Molleman, 2006). There are also evidences for the interaction between the endocannabinoid system and KORs. For example, $\Delta$-(9)tetrahydrocannabinol's(THC) acute antinociceptive effects can be attenuated by KOR antagonist norbinaltorphimine (nor-BNI) (Smith et al., 1994). Other reports have highlighted the interaction between them at the level of nociception (Haller et al., 2008) or inflammation (Capasso et al., 2008). There are also data referring to the overlapping neuroanatomical localization and cross-talk between $\mathrm{CB}_{1}$ and the $\mathrm{KOR}$ : $\mathrm{CB}_{1}$ receptors and dynorphin are colocalized in striatal neurons (Hohmann and Herkenham, 2000) and also the KOR activity increases in the absence of $\mathrm{CB}_{1}$ receptors in mouse caudate putamen (Urigüen et al., 2005).

Recently there has been an increasing number of reports demonstrating the direct effect of rimonabant on opioid receptors (Cinar and Szücs, 2009; Fong et al., 2009; Kathmann et al., 2006), in the case of MOR and DOR, rimonabant seems to have an antagonistic character (Seely et al., 2012; Zádor et al., 2014, 2012). Lockie and coworkers have shown that the endogenous mu opioid system is involved in modulating the metabolic effects of rimonabant whereas the endogenous kappa opioid system modulates the mood related properties of rimonabant after a high dose, chronic administration (Lockie et al., 2011).

Stimulated by the observations that the mood related effects of rimonabant are linked to the $\kappa$-opioid system, we first investigated whether rimonabant can directly interact with the KOR at the ligand-receptor and receptor signaling level. In the next step, for our in vivo studies we applied an acute low dose to avoid the unspecificity of this compound that frequently occurs upon high dose, chronic administration and monitored the impact of rimonabant on KOR mediated G-protein activation, KOR protein 
expression rate and how all this contributes to depression- and anxiety-like behavior. Using Chinese hamster ovary cell lines (CHO) transfected with rat KOR (CHO-rKOR) as well as transgenic mouse lines lacking either $\mathrm{CB}_{1}$ or both $\mathrm{CB}_{1} / \mathrm{CB}_{2}$ cannabinoid receptors, we show that rimonabant cannabinoid receptor independently reduces KOR function at the level of ligand binding, receptor mediated G-protein activity and protein expression rate, which overall leads to altered anxiety like behavior. To the best of our knowledge, this is the first report linking the effect of rimonabant to the KOR system at signaling, protein expression and behavioral level in such a pharmacological application. 


\section{MATERIALS AND METHODS}

\subsection{Chemicals}

Tris-HCl, EGTA, $\mathrm{NaCl}, \mathrm{MgCl}_{2} \times 6 \mathrm{H}_{2} \mathrm{O}$, GDP, the GTP analogue GTP $\gamma \mathrm{S}$, the DOR specific agonist peptide DPDPE were purchased from Sigma-Aldrich (St. Louis, MO, USA). The MOR agonist DAMGO was obtained from Bachem Holding AG (Bubendorf, Switzerland). The KOR agonist peptide dynorphin (1-11) was synthesized by the Isotope Laboratory of Biological Research Center (Szeged, Hungary), while the KOR antagonist nor-BNI was purchased from Tocris Bioscience (Bristol, UK). The opioid antagonist naloxone was kindly provided by the company Endo Laboratories DuPont de Nemours (Wilmington, DE, USA). SR141716 (rimonabant) was acquired from Santa Cruz (Dallas, Texas, USA). The radiolabelled GTP analogue, $\left[{ }^{35} \mathrm{~S}\right] \mathrm{GTP} \gamma \mathrm{S}$ (specific activity: $>1000$ $\mathrm{Ci} / \mathrm{mmol}$ ) was purchased from the Isotope Institute Ltd. (Budapest, Hungary). The tritiated [Phenyl-3, 4- $\left.{ }^{3} \mathrm{H}\right]-\mathrm{U} 69593\left(\left[{ }^{3} \mathrm{H}\right] \mathrm{U} 69593\right.$; specific activity: 30-60 Ci/mmol) was purchased from PerkinElmer (Boston, USA). The KOR internal rabbit polyclonal antibody was purchased from Invitrogen (Paisley, UK; catalogue number: 44302G). Rimonabant was dissolved in DMSO and similar to the other applied receptor ligands, was stored in $1 \mathrm{mM}$ stock solution at $-20^{\circ} \mathrm{C}$.

\subsection{Animals}

$\mathrm{CB}_{1}$ receptor knockout $\left(\mathrm{CB}_{1}\right.$ K.O.) mice and their controls were provided by Dr. György M. Nagy's laboratory (Semmelweis University, Budapest) and were originally generated on CD1 background in Dr.Ledent's lab as described earlier (Ledent et al., 1999). The $\mathrm{CB}_{1} / \mathrm{CB}_{2}$ receptor double knockout mice $\left(\mathrm{CB}_{1} / \mathrm{CB}_{2}\right.$ K.O.; C57BL/6J background) were generated in Dr. Andreas Zimmer's laboratory (University of Bonn, Germany) as described previously (Járai et al., 1999). The C57BL/6J wild type mice strains were bought from the local animal house of the Biological Research Center (Szeged, Hungary). All animals were two months old and the genders were half male and half female for the binding assays and Western blot studies, in case of behavior studies all 
tested animals were male. All animals were housed at $21-24{ }^{\circ} \mathrm{C}$ under a 12:12 light: dark cycle and were provided with water and food ad libitum. All housing and experiences were conducted in accordance with the European Communities Council Directives (86/609/ECC) and the Hungarian Act for the Protection of Animals in Research (XXVIII.tv. 32.§).

\subsection{Animal treatments}

Rimonabant was dissolved in DMSO for $\left[{ }^{35} \mathrm{~S}\right] \mathrm{GTP} \gamma \mathrm{S}$ binding assays and Western blot studies. For behavioral studies rimonabant together with nor-BNI were dissolved in DMSO/ethanol/Tween80. Animals received a single intra peritoneal (i.p.) injection of 0.1 or $1 \mathrm{mg} / \mathrm{kg}$ rimonabant, or $1 \mathrm{mg} / \mathrm{kg}$ nor-BNI, or the combination of $1 \mathrm{mg} / \mathrm{kg}$ nor-BNI and $0.1 \mathrm{mg} / \mathrm{kg}$ rimonabant. Control groups received only vehicle. In the combined treatment nor-BNI was administered 30 min prior to rimonabant injection, so nor-BNI could occupy KOR before rimonabant is administered. $24 \mathrm{~h}$ after the treatment animals were decapitated and their forebrains were prepared for binding assays, or were used for behavioral studies.

\subsection{Forebrain membrane preparations}

Forebrain membrane fractions from $\mathrm{CB}_{1}$ K.O. and $\mathrm{CB}_{1} / \mathrm{CB}_{2}$ K.O. mice and their wild type controls were prepared as previously described (Benyhe et al., 1997) right up to the point where the membrane homogenate was prepared for the $\left[{ }^{35} \mathrm{~S}\right] \mathrm{GTP} \gamma \mathrm{S}$ binding assay. In this procedure the sucrose was removed by centrifugation (40 $000 \mathrm{~g}, 20 \mathrm{~min}$, $4^{\circ} \mathrm{C}$ ) and the pellet was suspended with ice-cold TEM buffer to obtain the appropriate protein content for the assay $(\sim 10 \mu \mathrm{g} / \mathrm{ml})$. 


\subsection{Cell culture and cell membrane preparations}

CHO-rKOR cells overexpressing rat KORs were provided by Dr. Zvi Vogel (Rehovot, Israel) and were characterized earlier (Avidor-Reiss et al., 1995). Briefly the cells were grown in Dulbecco's modified Eagle's medium and in $\alpha$-minimum essential medium, respectively. Both media were supplemented with $10 \%$ fetal calf serum, $2 \mathrm{mM}$ glutamine, $100 \mathrm{IU} / \mathrm{ml}$ penicillin, $100 \mathrm{mg} / \mathrm{ml}$ streptomycin, $25 \mathrm{mg} / \mathrm{ml}$ fungi zone and 0.5 $\mathrm{mg} / \mathrm{ml}$ geneticin and were kept in culture at $37^{\circ} \mathrm{C}$ in a humidified atmosphere consisting of $5 \% \mathrm{CO}_{2}$ and $95 \%$ air (Zádor et al., 2012).

Cell membranes were prepared for competition binding experiments as we previously described (Zádor et al., 2012). For the $\left[{ }^{35} \mathrm{~S}\right] \mathrm{GTP} \gamma \mathrm{S}$ binding assays the membrane homogenate was prepared similarly except that the cells were homogenized in

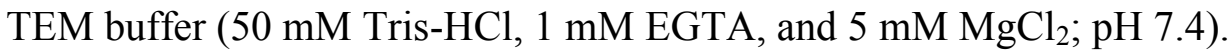

\subsection{Radioligand competition binding assays}

In competition binding experiments we measure the inhibition of fix concentrations of specific radioligand binding in the presence of increasing concentrations of unlabeled competitor ligands. Radioligand competition binding assays were applied to investigate the direct binding affinity of rimonabant towards KOR.

Aliquots of frozen CHO-rKOR membranes were first centrifuged $(40000 \times \mathrm{g}, 20$ $\min , 4^{\circ} \mathrm{C}$ ) to remove sucrose and the pellets were suspended in $50 \mathrm{mM}$ Tris- $\mathrm{HCl}$ buffer (pH 7.4). Membranes were incubated with gentle shaking at $30^{\circ} \mathrm{C}$ for $30 \mathrm{~min}$ in a final volume of $1 \mathrm{ml}$ with $10^{-10}-10^{-5} \mathrm{M}$ concentration interval of unlabeled rimonabant together with $1 \mathrm{nM}$ of $\left[{ }^{3} \mathrm{H}\right] \mathrm{U} 69593$. Total binding was measured in the presence of radioligand, in the absence of the displacer ligands. The non-specific binding was determined in the presence of $10 \mu \mathrm{M}$ unlabeled naloxone. The reaction was terminated by rapid filtration under vacuum (Brandel M24R Cell Harvester), and washed three times with $5 \mathrm{ml}$ ice-cold $50 \mathrm{mM}$ Tris- $\mathrm{HCl}$ (pH 7.4) buffer through Whatman GF/B glass fiber filters washed in 3\% polyethylenimine for $60 \mathrm{~min}$ (to reduce non-specific binding of the radioligand). The radioactivity of the filters was detected in UltimaGold ${ }^{\mathrm{TM}} \mathrm{MV}$ aqueous 
scintillation cocktail with Packard Tricarb 2300TR liquid scintillation counter. The competition binding assays were performed in duplicate and repeated at least three times.

\subsection{Functional $\left[{ }^{35} S\right] G T P \gamma S$ binding assays}

Functional $\left[{ }^{35} \mathrm{~S}\right] \mathrm{GTP} \gamma \mathrm{S}$ binding experiments monitor the nucleotide exchange process of the $\mathrm{G}_{\alpha}$-protein using a non-hydrolysable radiolabeled GTP analog, $\left[{ }^{35} \mathrm{~S}\right] \mathrm{GTP} \gamma \mathrm{S}$ in the presence of increasing concentrations of the observed ligand.

The assays were performed as previous described, with slight modifications (Sim et al., 1995; Traynor and Nahorski, 1995). Membrane fractions of CHO-rKOR, $\mathrm{CB}_{1}$ K.O., $\mathrm{CB}_{1} / \mathrm{CB}_{2}$ K.O. and wild type mouse forebrains were incubated in a final volume of $1 \mathrm{ml}$ at $30^{\circ} \mathrm{C}$ for $60 \mathrm{~min}$ in a Tris-EGTA buffer (pH 7.4). The buffer was composed of $50 \mathrm{mM}$ Tris-HCl, $1 \mathrm{mM}$ EGTA, $3 \mathrm{mM} \mathrm{MgCl} 2,100 \mathrm{mM} \mathrm{NaCl}$, containing $0.05 \mathrm{nM}\left[{ }^{35} \mathrm{~S}\right] \mathrm{GTP} \gamma \mathrm{S}$ $\left(20 \mathrm{MBq} / 0.05 \mathrm{~cm}^{3}\right)$ and $30 \mu \mathrm{M}$ GDP. The incubation was performed together with the indicated concentrations of dynorphin (1-11), rimonabant, nor-BNI, DAMGO or DPDPE. Total binding $(\mathrm{T})$ was measured in the absence of the ligands, non-specific binding (NS) was determined in the presence of $10 \mu \mathrm{M}$ unlabeled GTP $\gamma \mathrm{S}$ and subtracted from total binding. The difference (T-NS) represents basal activity. Bound and free $\left[{ }^{35} \mathrm{~S}\right] \mathrm{GTP} \gamma \mathrm{S}$ were separated by vacuum filtration through Whatman GF/B filters with Brandel M24R Cell harvester. Filters were washed three times with $5 \mathrm{ml}$ ice-cold buffer ( $\mathrm{pH}$ 7.4), and the radioactivity of the dried filters was detected in UltimaGold ${ }^{\mathrm{TM}} \mathrm{MV}$ scintillation cocktail with Packard Tricarb 2300TR liquid scintillation counter. The $\left[{ }^{35} \mathrm{~S}\right] \mathrm{GTP} \gamma \mathrm{S}$ binding experiments were performed in triplicates and repeated at least three times. 


\subsection{Western blot}

In Western blot studies wild type and $\mathrm{CB}_{1}$ K.O. mice were used. Both $\mathrm{CB}_{1}$ K.O. animals and the corresponding controls received a single dose of vehicle or $0.1 \mathrm{mg} / \mathrm{kg}$ rimonabant i.p. and $24 \mathrm{~h}$ after the injection the forebrains were prepared and the total protein was isolated as previously described (Lénárt et al., 2012). Western blot experiments were performed according to Lénárt and co-workers (Lénárt et al., 2012). The KOR antibody was diluted to 1:1000 and for loading control GAPDH was used. Signals were enhanced by Luminata Forte Western HRP Substrate (Millipore) and detected by a Nikon CCD $28 \mathrm{~mm}$ camera. Each group contained 5 animals and the experiments were repeated at least three times.

\subsection{Forced swimming test (FST)}

Forced swimming tests (FST) quantifies the depression-like behavior of the animal by monitoring the immobility period of the animal in water during the trial. The more the animal is immobile the more it shows depression-like behavior (Castagné et al., 2011). For the FST studies wild type male C57BL/6J mice were used. They received a single dose of vehicle or $0.1 \mathrm{mg} / \mathrm{kg}$ i.p. rimonabant. The tests were performed $24 \mathrm{~h}$ following the treatments. The FST studies were conducted according to Gaszner and co-workers (Gaszner et al., 2012). Animals were placed individually in plastic cylinders (diameter $11.5 \mathrm{~cm}$, height $25 \mathrm{~cm}$ ) containing $19 \mathrm{~cm}$ of water maintained at $24 \pm 1^{\circ} \mathrm{C}$ temperature. Mice were unable to escape or touch the bottom of the cylinder. Each animal was forced to swim for 6 minutes, in which the duration of immobility was monitored manually in the last 4 minutes. Trials were recorded by digital camera (Nikon Coolpix L10) and analyzed later. Animals were placed 2 hours before the test to the measuring room and each animal was separated right before and right after the trial. At least eight animals per group were used and the tests were repeated at least three times, with at least 3 weeks interval in case of the same animal group. 


\subsection{Elevated plus maze test (EPM)}

Elevated plus maze tests (EPM) is used to examine the anxiety-like behavior of the animals by monitoring the fear of open spaces or heights of rodents (Walf and Frye, 2007). Wild type male C57BL/6J mice were used, receiving a single i.p. dose of vehicle or rimonabant (at the dose of 0.1 or $1 \mathrm{mg} / \mathrm{kg}$ ), or nor-BNI (at the dose of $1 \mathrm{mg} / \mathrm{kg}$ )or 1 $\mathrm{mg} / \mathrm{kg}$ nor-BNI in combination with $0.1 \mathrm{mg} / \mathrm{kg}$ rimonabant. The animals were tested $24 \mathrm{~h}$ after the treatments. The experimental setup was accomplished according to Walf and Frye (Walf and Frye, 2007). Each animal was measured for 5 minutes and the tests were performed in a separate room. Animals were placed next to the measuring room $24 \mathrm{~h}$ before the test. Trials were recorded by camera using the SMART Video Recording System (Panlab, Harvard Apparatus). Animals were separated before and after the trials. At least eight animals per group were used and the tests were repeated at least three times with at least one month interval in case of the same animal group.

\subsection{Data analysis}

Competition binding experiments and $\left[{ }^{35} \mathrm{~S}\right] \mathrm{GTP} \gamma \mathrm{S}$ binding assay data were presented and analyzed as previously described by our group (Zádor et al., 2014). In competition binding experiments the total specific binding and the minimum level of non-specific binding was defined as $100 \%$ and $0 \%$ respectively. In the $\left[{ }^{35} \mathrm{~S}\right] \mathrm{GTP} \gamma \mathrm{S}$ binding assays the basal activity was settled as $100 \%$. Western blot results were analyzed with ImageJ image processing program. Each data was normalized to its own GAPDH data and then all data were normalized to the wild type control. FST results were video recorded and analyzed mechanically. The mouse was considered immobile when it stopped struggling, passively floated or performed small movements with only one of its legs to keep its head above the water. EPM test results were analyzed by the SMART Video Recording System, which monitored the time spent in the open arms and the distance traveled by the animals (for locomotor activity) among others. 


\subsection{Statistical analysis}

Statistical analyses were performed with GraphPad Prism 5.0. In case of two data sets unpaired t-test with two-tailed $\mathrm{P}$ value statistical analysis was used, while in case of three or more data sets One-way ANOVA with Bonferroni's Multiple Comparison post hoc test was performed to determine the significance level. In case of the binding assays since both the competitor and stimulator ligands were presented in the logarithm form, the curve fitting program could only calculate S.E.M. for the logarithm form of $\mathrm{IC}_{50}$ $\left(\log \mathrm{IC}_{50}\right)$ and $\mathrm{EC}_{50}(\log \mathrm{EC} 50)$ values. At the same time their antilogarithm form has also been indicated on the figures for better understanding. Significance was accepted at the $P$ $<0.05$ level. 


\section{RESULTS}

\subsection{Rimonabant directly inhibits KOR specific ligand binding in $\mathrm{CHO}-\mathrm{rKOR}$ membrane fractions, but only at micromolar range}

Because rimonabant is able to bind with low affinity to other GPCR's than the $\mathrm{CB}_{1}$ receptors (Pertwee, 2010), including the MORs and DORs (Cinar and Szücs, 2009; Kathmann et al., 2006; Seely et al., 2012; Zádor et al., 2014, 2012) we first tested its direct binding ability to KORs. The investigations were carried out in competition binding experiments with a tritiated KOR specific agonist ligand, U69593 ([ $\left.{ }^{3} \mathrm{H}\right] \mathrm{U} 69593$; $\sim 1 \mathrm{nM})$ in the presence of increasing concentrations of rimonabant $\left(10^{-11}-10^{-5} \mathrm{M}\right)$. To insure a better receptor-ligand interaction, the binding experiments were prepared on membrane fractions of $\mathrm{CHO}$ cells overexpressing rat $\mathrm{KOR}$ (CHO-rKOR).

Rimonabant was able to inhibit $\left[{ }^{3} \mathrm{H}\right] \mathrm{U} 69593$ specific binding by $20 \%$ at $1 \mu \mathrm{M}$ and by $60 \%$ at $10 \mu \mathrm{M}$ (Fig. $1 \mathrm{~A}$ ) concentration with a $5.17 \mu \mathrm{M} \mathrm{IC}_{50}$ value (Fig. 1B). These results indicate that rimonabant can interact directly with KOR, but only with low affinity. 


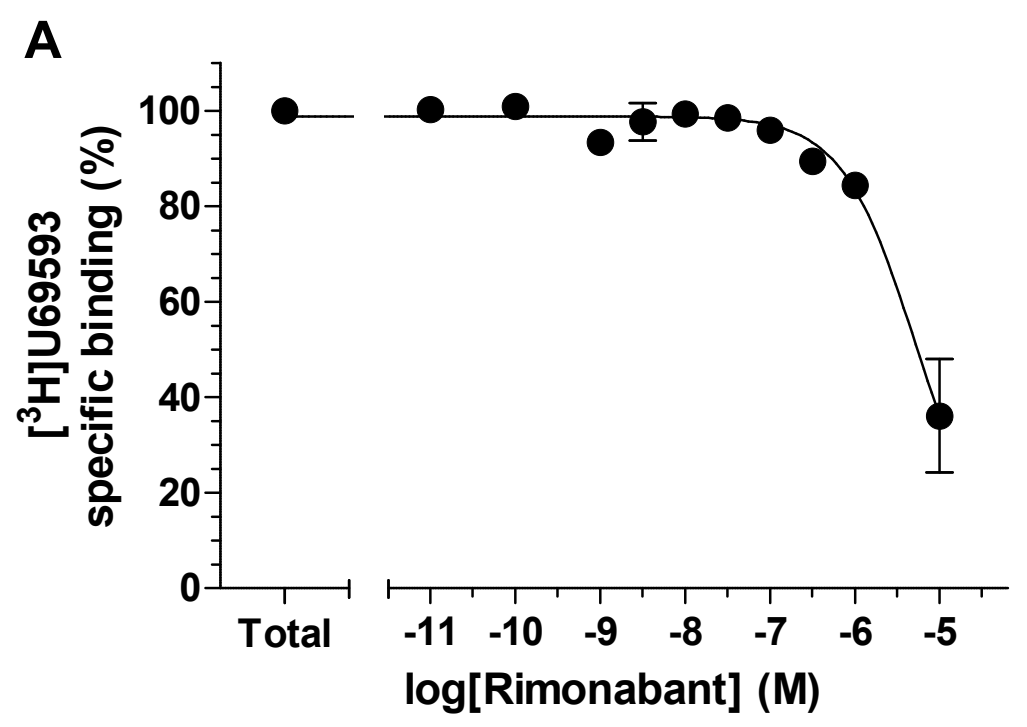

B

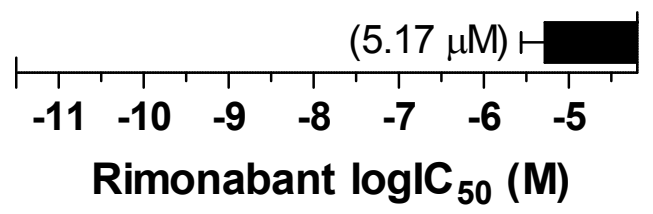

Fig. 1. Competition of rimonabant for the binding sites of $\left[{ }^{3} \mathrm{H}\right] \mathrm{U} 69593$ in CHO-rKOR membrane fractions. Membranes were incubated as described under section 2.6. (A) The figure represents the specifically bound fixed $(\sim 1 \mathrm{nM})$ concentrations of $\left.{ }^{3} \mathrm{H}\right] \mathrm{U} 69593$ in percentage in the presence of increasing $\left(10^{-10}-10^{-5} \mathrm{M}\right)$ concentrations of unlabeled rimonabant. "Total" on the $\mathrm{X}$ axis refers to the points which did not contain competitor ligands and also represents the total specific binding $(=100 \%)$ in the presence of either radioligand. (B) The calculated $\operatorname{logIC}_{50}$ (binding affinity) of unlabeled rimonabant. Points and columns represent means \pm S.E.M. for at least three experiments performed in duplicate. The antilogarithm form of $\operatorname{logIC} \mathrm{C}_{50}\left(\mathrm{IC}_{50}\right)$ value is presented in brackets. 


\subsection{Rimonabant has a direct impact on KOR G-protein activity in CHO-rKOR cell membranes}

Since rimonabant had a direct effect on KOR binding at higher concentrations, next we wanted to examine the impact of rimonabant on KOR mediated GPCR signaling. For this, again we used CHO-rKOR cell membrane preparations to avoid interactions with other opioid and cannabinoid receptors so to make certain that the observed effect of rimonabant on KOR G-protein is direct. The receptors G-protein activity was measured in functional $\left[{ }^{35} \mathrm{~S}\right] \mathrm{GTP} \gamma \mathrm{S}$ binding experiments.

Firstly we verified that the applied CHO-rKOR cell lines do not express MOR and DORs. As expected, the DOR specific DPDPE and the MOR specific DAMGO did not increase $\left[{ }^{35} \mathrm{~S}\right] \mathrm{GTP} \gamma \mathrm{S}$ binding at $10 \mu \mathrm{M}$ concentrations (Fig. 2A), thus we can confirm that the cell lines do not express neither MORs nor DORs. The neutral antagonistic and KOR mediated effect of nor-BNI was also confirmed, since1 $\mu \mathrm{M}$ concentrations of nor-BNI did not alter $\left[{ }^{35} \mathrm{~S}\right] \mathrm{GTP} \gamma \mathrm{S}$ specific binding significantly thus the KOR's basal activity remained unaltered (Fig. 2A). Further on, it significantly decreased dynorphin (1-11)-enhanced $\left[{ }^{35} \mathrm{~S}\right] \mathrm{GTP} \gamma \mathrm{S}$ specific binding as well (Fig. 2A).

In the next step we investigated the impact of rimonabant per se on KOR basal activity and we wanted to examine whether the possible effect can be reversed by norBNI. In $0.5 \mu \mathrm{M}$ concentrations rimonabant moderately decreased KOR basal activity which was indicated by the decreased $\left[{ }^{35} \mathrm{~S}\right] \mathrm{GTP} \gamma \mathrm{S}$ specific binding. This effect was reversed by nor-BNI (Fig. 2A). The reduction on KOR's basal activity was more pronounced and also significant in the presence of higher concentrations (1 and $10 \mu \mathrm{M})$ of rimonabant (Fig. 2A). Interestingly $1 \mu \mathrm{M}$ nor-BNI could only reverse the inhibitory effect of rimonabant when it was applied in $1 \mu \mathrm{M}$ (Fig. 2A), which indicates that the inverse agonistic effect of rimonabant at $10 \mu \mathrm{M}$ concentrations is not KOR related.

In the next step we activated the KOR with increasing concentrations $\left(10^{-10}-10^{-5} \mathrm{M}\right)$ of the KOR selective agonist dynorphin (1-11) and analyzed the KOR-mediated G-protein activity in the presence of $0.5,1$ and $10 \mu \mathrm{M}$ of rimonabant. The experiments were again accomplished in functional $\left[{ }^{35} \mathrm{~S}\right] \mathrm{GTP} \gamma \mathrm{S}$ binding studies performed in CHO-rKOR cell membranes. Our results revealed that rimonabant dose 
dependently inhibited the specific $\left[{ }^{35} \mathrm{~S}\right] \mathrm{GTP} \gamma \mathrm{S}$ binding of KOR-mediated G-protein during receptor activation (Fig. $2 \mathrm{~B}$ ), as a result the maximal efficacy $\left(\mathrm{E}_{\max }\right)$ of the receptors G-protein also reduced dose dependently (Fig. 2C). The inhibition was the most elicit at 1 and $10 \mu \mathrm{M}$ concentrations (Fig. $2 \mathrm{C}$ ). The potency $\left(\mathrm{EC}_{50}\right)$ of the activator ligand was also dose-dependently decreased (data not shown, control: $32.6 \mathrm{nM}$, $0.5 \mu \mathrm{M}$ rim.: $42.9 \mathrm{nM}, 1 \mu \mathrm{M}$ rim.: $75.3 \mathrm{nM}, 10 \mu \mathrm{M}$ rim.: $138.7 \mathrm{nM}$ ), at $10 \mu \mathrm{M}$ concentrations the reduction was significant (One-way ANOVA, Bonferroni's Multiple Comparison post hoc test, $\mathrm{P}<0.05)$. These results correspond with our competition binding experiments (see section 3.1, Fig.1A and B). 


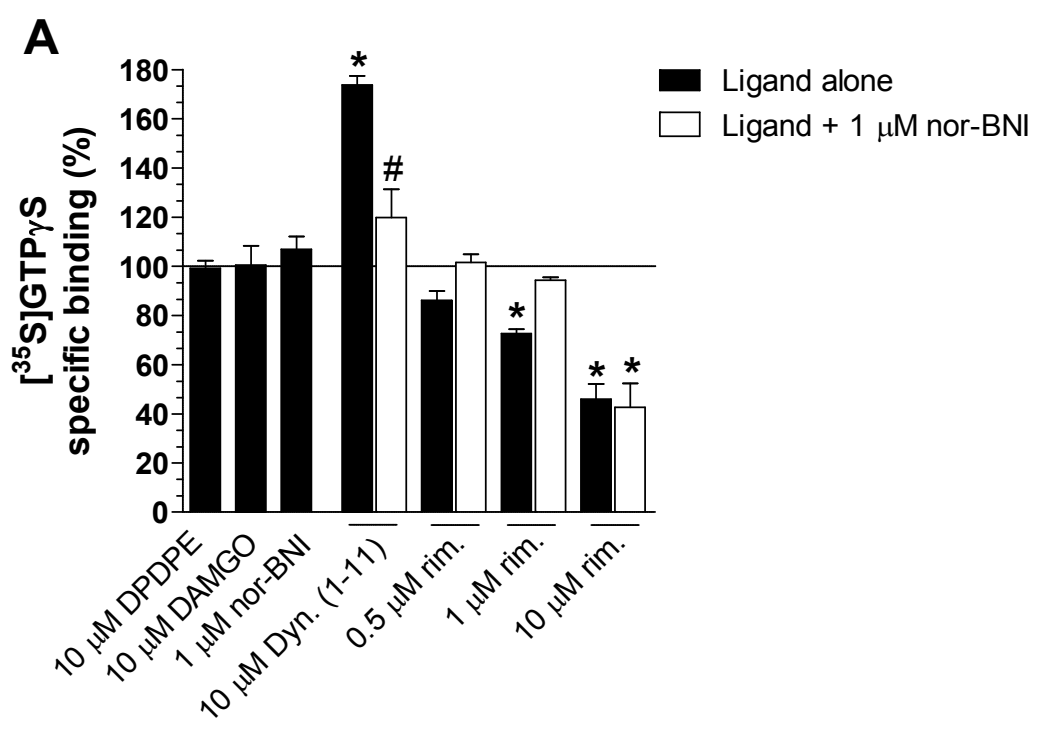

B

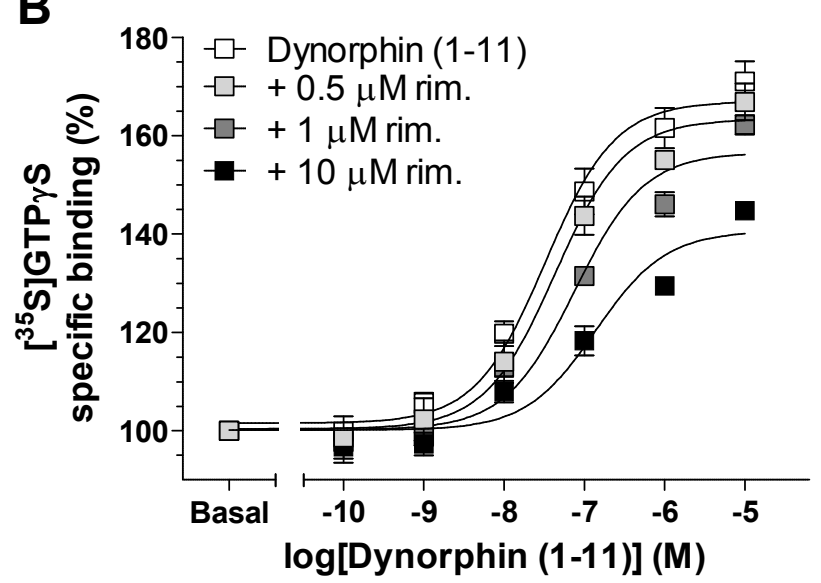

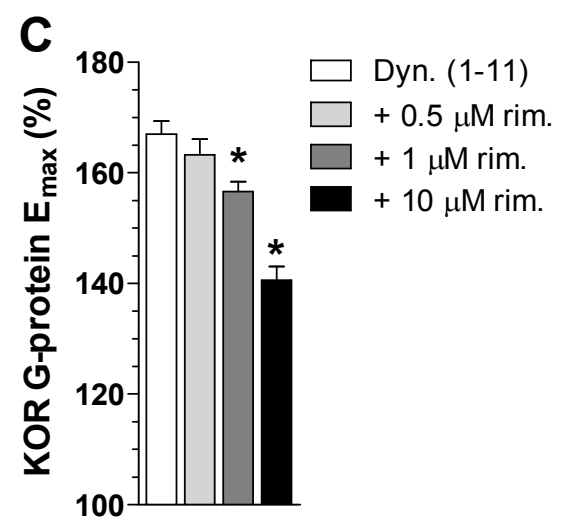

Fig. 2. The effect of rimonabant on KOR G-protein activity in ligandmodulated $\left[{ }^{35} \mathrm{~S}\right] \mathrm{GTP} \gamma \mathrm{S}$ binding assays, in CHO-rKOR cell membranes. Membranes were incubated according to section 2.7. (A) The figure represents the specifically bound $\left[{ }^{35} \mathrm{~S}\right] \mathrm{GTP} \gamma \mathrm{S}$ in percentage in the presence of the indicated ligand concentrations alone or together with $1 \mu \mathrm{M}$ nor-BNI. * indicates the significant alterations in specifically bound $\left[{ }^{35} \mathrm{~S}\right] \mathrm{GTP} \gamma \mathrm{S}$, compared to basal activity (One-way ANOVA, Bonferroni's Multiple Comparison post hoc test; $10 \mu \mathrm{M}$ dyn. (1-11): $\mathrm{P}<0.001,1 \mu \mathrm{M}$ rim.: $\mathrm{P}<0.05,10 \mu \mathrm{M}$ rim.: $\mathrm{P}<0.001)$. \# indicates the significant reduction in the specifically bound $\left[{ }^{35} \mathrm{~S}\right] \mathrm{GTP} \gamma \mathrm{S}$ during dynorphin (1-11) stimulation in the presence of nor-BNI compared to dynorphin (1-11) alone (One-way ANOVA, Bonferroni's Multiple Comparison post hoc test; $\mathrm{P}<0.001)$. The basal activity $(=100 \%)$ is indicated by the line. $(\boldsymbol{B})$ The figure indicates the specifically bound $\left[{ }^{35} \mathrm{~S}\right] \mathrm{GTP} \gamma \mathrm{S}$ in percentage in the presence of increasing concentrations $\left(10^{-10}-10^{-5} \mathrm{M}\right)$ of dynorphin (1-11) in the absence or presence of the indicated rimonabant concentrations. "Basal" on the $\mathrm{X}$ axis refers to the points which did not contain dynorphin (1-11). (C) The calculated $\mathrm{E}_{\max }$ (maximal efficacy) value of KOR G-protein over basal activity $(100 \%)$ after agonist stimulation in the presence or absence of the indicated rimonabant concentrations. Points and columns represent means \pm S.E.M. for at least 
three experiments performed in triplicate. * indicates the significant reduction in $\mathrm{E}_{\max }$ values in the presence of rimonabant compared to dynorphin (1-11) alone (One-way ANOVA, Bonferroni's Multiple Comparison post hoc test; $1 \mu \mathrm{M}$ rim.: $\mathrm{P}<0.05 ; 10 \mu \mathrm{M}$ rim.: $\mathrm{P}<0.001)$. 


\subsection{Rimonabant inhibited KOR G-protein activity $C B_{1}$ and $C B_{2}$ cannabinoid receptor independently in dynorphin (1-11)-stimulated ${ }^{35} S J G T P \gamma S$ binding performed in mouse forebrain membranes}

In the previous set of experiments on KOR-CHO cell lines we have seen that rimonabant was capable of altering KOR mediated G-protein activity alone, or via inhibiting dynorphin stimulated activation. We have also shown that this is likely due to the specific binding ability of rimonabant to KOR at lower micromolar concentrations as it was able to partially displace $\left[{ }^{3} \mathrm{H}\right] \mathrm{U} 69593$. Thus, if we hypothesize that rimonabant has an influence on KOR mediated signaling at the lower micromolar concentrations the role of other receptors that are in a very close proximity of KOR - such as the $\mathrm{CB}_{1}$ cannabinoid receptor - should be considered. Therefore, we used $\mathrm{CB}_{1}$ single knockout mice to follow the role of $\mathrm{CB}_{1}$ receptors in rimonabant altered dynorphin (1-11) stimulated functional $\left[{ }^{35} \mathrm{~S}\right] \mathrm{GTP} \gamma \mathrm{S}$ binding. Furthermore, because there are increasing numbers of publications showing the neuronal presence of cannabinoid receptor type 2 $\left(\mathrm{CB}_{2}\right)$ in the brain moreover their interaction with opioid receptors (Páldyová et al., 2008), we looked at the effect of rimonabant on dynorphin (1-11) stimulated G-protein activity in $\mathrm{CB}_{1} / \mathrm{CB}_{2}$ double knockout mice as well. For all our experiments on mouse brain membrane preparations only the forebrain part was used, in which the KORs, and the $\mathrm{CB}_{1}, \mathrm{CB}_{2}$ receptors are in eligible amount (Lever, 2007; Sim and Childers, 1997; Svízenská et al., 2008) and importantly this brain region is mainly responsible for emotion and anxiety formation at the central (eg. amygdala) and highest cortical levels (Beckstead et al., 1979; Schwarzer, 2009; Simon et al., 1979; Tanaka et al., 2000).

In wild type forebrain membranes the inhibitory effect of rimonabant upon KOR-mediated G-protein maximal efficacy occurred as well in $1 \mu \mathrm{M}$ concentrations during dynorphin (1-11)-stimulated KOR activation (Fig. 3A-C). However the potency of the activator ligand was unaffected (data not shown). Interestingly similar results were observed in $\mathrm{CB}_{1}$ K.O. and $\mathrm{CB}_{1} / \mathrm{CB}_{2}$ K.O. mouse forebrain membranes (Fig. 3A-C), additionally the lack of either cannabinoid receptors did not alter the dynorphin (1-11)-stimulated KOR G-protein activity significantly (Fig. 3A-C).

Taken together our in vitro data on the influence of rimonabant on KOR, we demonstrated in competition binding experiments that rimonabant was able to displace 
the KOR specific ligand but only at micromolar concentrations, and with a high $\mathrm{IC}_{50}$ value. Rimonabant also effected KOR signaling: the compound decreased the receptors G-protein activity in $\mathrm{CHO}$ cell membranes over expressed with human KORs and in mouse forebrains $\mathrm{CB}_{1}$ and $\mathrm{CB}_{2}$ receptor independently. 

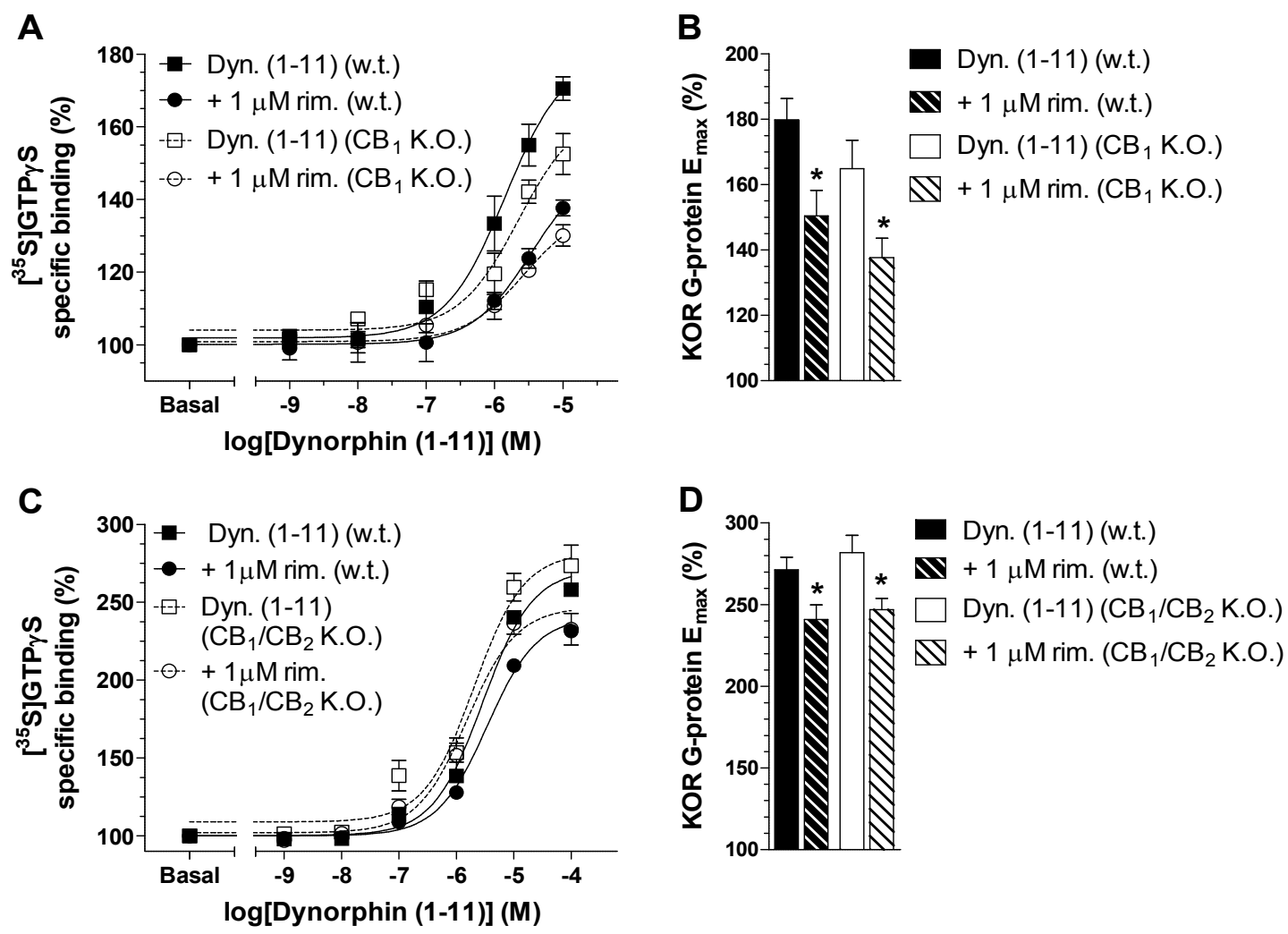

igure 3The effect of rimonabant on KOR G-protein activity in dynorphin (111)-stimulated $\left.{ }^{35} S\right] G T P \gamma S$ binding assays, in wild type and in $C B_{1}$ K.O. $(A$ and $B)$ or $C B_{1} / C_{2}$ double K.O. ( $C$ and $D$ ) mouse forebrain membranes. Forebrain membranes were incubated as described under section $2.7(\boldsymbol{A}$ and $\boldsymbol{C})$. The figures represents the specifically bound $\left[{ }^{35} \mathrm{~S}\right] \mathrm{GTP} \gamma \mathrm{S}$ in percentage in the presence of increasing concentrations $\left(10^{-10}-10^{-4} \mathrm{M}\right)$ of dynorphin (1-11) in the absence or presence of $1 \mu \mathrm{M}$ rimonabant. "Basal" on the X axis refers to the points which did not contain dynorphin (1-11) (B and D). The figures represent the calculated $\mathrm{E}_{\max }$ (maximal efficacy) value of KOR G-protein activity after dynorphin (1-11) stimulation in the presence or absence of $1 \mu \mathrm{M}$ rimonabant. Points and columns represent means \pm S.E.M. for at least three experiments performed in triplicate. ${ }^{*}$ indicates the significant reduction in $\mathrm{E}_{\max }$ values in the presence of rimonabant compared to dynorphin (1-11) alone (unpaired t-test, two-tailed $\mathrm{P}$ value; $\mathrm{P}<0.05$ ). 
3.4. Acute treatment with low dose of rimonabant inhibits dynorphin (1-11)-stimulated $\left.{ }^{35} S\right] G T P \gamma S$ binding in wild type and $C B_{1}$ K.O. mouse forebrain membranes

Our in vitro studies on CHO-rKOR cell lines as well as on forebrain membrane preparations have shown the inhibitory action of rimonabant on KOR mediated G protein activity that was $\mathrm{CB}_{1}$ and $\mathrm{CB}_{2}$ receptor independent. Next, we wanted to investigate the impact of rimonabant on KOR activity upon in vivo administration. There are many publications representing the unspecific effect of rimonabant upon chronic administration (Beyer et al., 2010; Christensen et al., 2007) moreover, relating it to kappa opioid receptor mediated mood behavior (Lockie et al., 2011). However, the effect of an acute, low dosage of rimonabant on KOR system is not well established. Therefore, we administered a single $0.1 \mathrm{mg} / \mathrm{kg}$ dose of rimonabant intra peritoneally (i.p.) into $\mathrm{CB}_{1} \mathrm{~K}$.O. mice and into their corresponding controls. $24 \mathrm{~h}$ after the treatment the animals were sacrificed and the KOR mediated G-protein activity was measured in functional $\left[{ }^{35} \mathrm{~S}\right] \mathrm{GTP} \gamma \mathrm{S}$ binding experiments on the forebrain region.

Rimonabant was able to significantly decrease the maximal efficacy of dynorphin (1-11)-stimulated KOR mediated G-protein activation in $\mathrm{CB}_{1} \mathrm{KO}$ mouse forebrain membranes and the observed inhibition was comparable with the corresponding controls (Fig. 4), yet again indicating a $\mathrm{CB}_{1}$ receptor independent effect. The potency of dynorphin (1-11) remained unaltered (data not shown). 

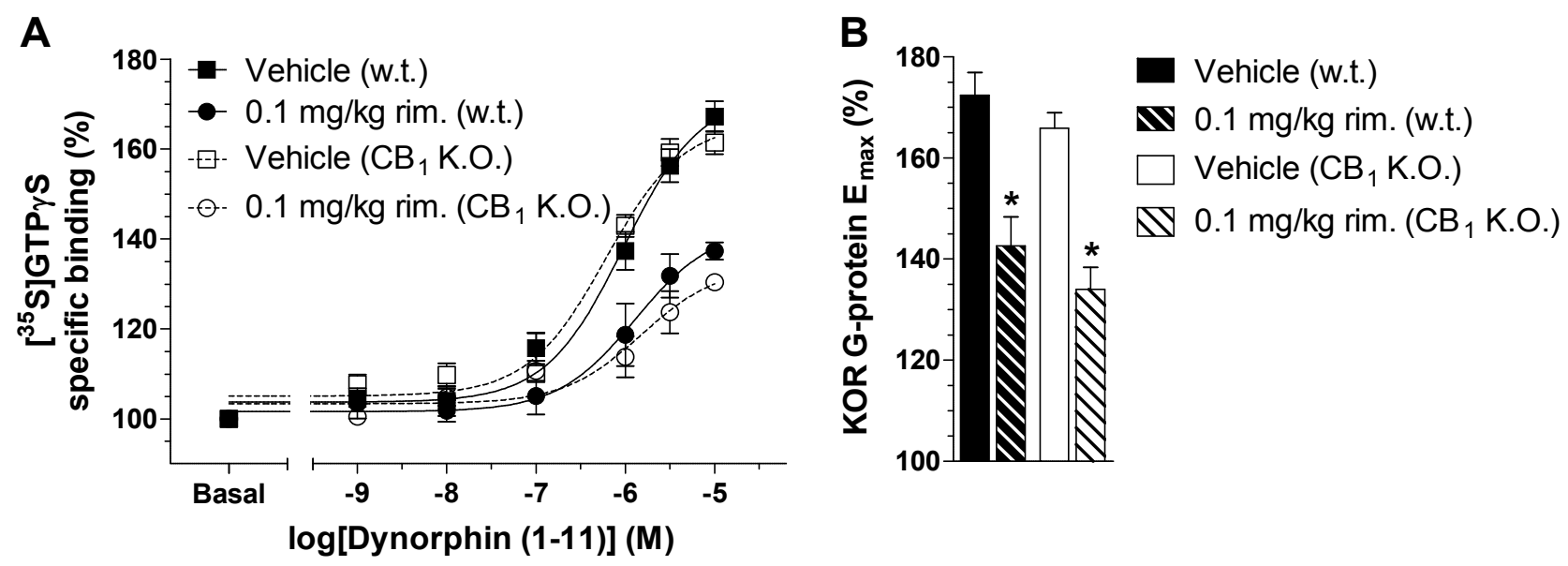

Figure 4 The acute low dose effect of rimonabant on KOR G-protein activity in dynorphin (1-11)-stimulated $\left[{ }^{35} \mathrm{~S}\right] \mathrm{GTP} \gamma \mathrm{S}$ binding assays, in wild type and in $\mathrm{CB}_{1}$ K.O. mouse forebrain membranes. Animal treatments were accomplished as described under section 2.3 and the forebrain membranes were incubated as discussed in section 2.7. (A) The figure represents the specifically bound $\left[{ }^{35} \mathrm{~S}\right] \mathrm{GTP} \gamma \mathrm{S}$ in percentage in the presence of increasing concentrations $\left(10^{-9}-10^{-5} \mathrm{M}\right)$ of dynorphin (1-11) after acute low dose rimonabant treatment. "Basal" on the $\mathrm{X}$ axis refers to the points which did not contain dynorphin (1-11). (B) The figure represents the calculated $\mathrm{E}_{\max }$ (maximal efficacy) value of KOR G-protein activity during dynorphin (1-11) stimulation after acute rimonabant. Points and columns represent means \pm S.E.M. for at least three experiments performed in triplicate. * indicates the significant reduction in $\mathrm{E}_{\max }$ values after acute low dose rimonabant treatment compared to vehicle (unpaired t-test, two-tailed $\mathrm{P}$ value; $\mathrm{P}<0.05)$. 
3.5. Acute effect of low dose rimonabant decreases KOR protein expression levels in both wild type and $C B_{1}$ K.O. mouse forebrains in Western blot studies

In the previous set of experiments we have shown that a single i.p. injection of $0.1 \mathrm{mg} / \mathrm{kg}$ rimonabant is able to alter KOR mediated intracellular signaling in a $\mathrm{CB}_{1}$ receptor independent manner. In the next step we addressed to look at the effect of rimonabant on other possible levels, therefore we examined at the KOR protein expression $24 \mathrm{~h}$ after rimonabant treatment.

We have seen that $0.1 \mathrm{mg} / \mathrm{kg}$ i.p. rimonabant treatment slightly, but significantly decreased relative KOR protein expression rate in wild type and also in $\mathrm{CB}_{1}$ K.O. mouse forebrains compared to vehicle treated mice (Fig. 5B). These results indicate a $\mathrm{CB}_{1}$ receptor independent inhibition of a single i.p. dose of rimonabant on KOR protein expression level. However since the reduction was minor, the blot did not reflect the quantificational results (Fig. 5A). 

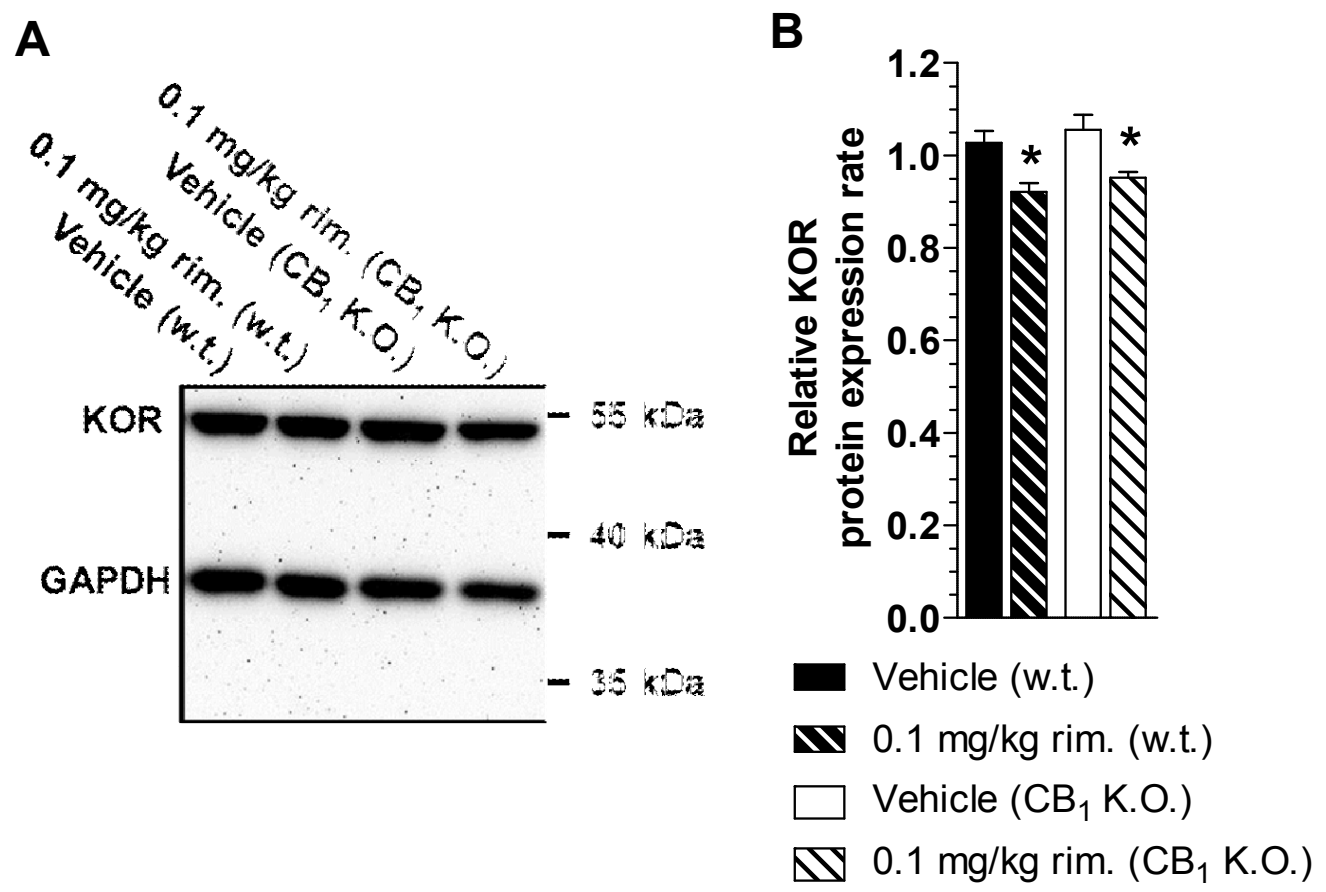

Figure 5 The effect of acute low dose rimonabant treatment on KOR protein expression levels in Western blot studies in wild type and in $\mathrm{CB}_{1}$ K.O. mouse forebrains. Animal treatments and Western blot experiments were accomplished as described under section 2.3 and 2.8 respectively. (A) The figure represents the detected KOR expression levels in control and after rimonabant treatment in wild type and in $\mathrm{CB}_{1}$ K.O. mouse forebrains. The expression level of the housekeeping gene GAPDH is also indicated as an internal for control. (B) The figure represents the quantification of blotting experiments. Columns represent means \pm S.E.M. for at least three experiments performed in four parallels. * indicates significant reduction in relative KOR protein expression rate after acute low dose of rimonabant compared to vehicle (unpaired t-test, two-tailed $\mathrm{P}$ value; $\mathrm{P}<0.05)$. 


\subsection{Rimonabant modulates anxiety-like but not depression-like behavior, when administered acutely at $0.1 \mathrm{mg} / \mathrm{kg}$ dose, which can be reversed by KOR antagonist}

As the KOR system is known to have a major impact on mediating depression and anxiety (Bals-Kubik et al., 1993; Carlezon et al., 2009, 2006; Mague et al., 2003; Pfeiffer et al., 1986; Wadenberg, 2003) our final goal was to test whether all the inhibitory actions provoked by rimonabant at the KOR signaling and KOR protein expression level have any consequences at behavioral level. We have performed elevated plus maze test (EPM) (Walf and Frye, 2007), a widely accepted behavioral test for anxiety-like behavior, and forced swim test (FST) (Castagné et al., 2011), a conventional test for depression-like behavior.

In the EPM studies we first tested the anxiolytic effect of nor-BNI, a KOR antagonist. We have seen that mice treated with $1 \mathrm{mg} / \mathrm{kg}$ nor-BNI spent more time in open space (Fig. 6A) when compared to the vehicle treated animals which goes along with previous reports (Schwarzer, 2009). Upon a single dose of $0.1 \mathrm{mg} / \mathrm{kg}$ rimonabant the mice spent also more time in open space, showing an anxiolytic-like behavior (Fig 6A). The extent of this effect is not dose dependent as mice treated with $1 \mathrm{mg} / \mathrm{kg}$ rimonabant show comparable results (Fig 6A). Interestingly, the anxiolytic effect of rimonabant could be reversed by pretreatment with nor-BNI, showing that KORs are involved in this effect. Finally, the mice from the different groups showed comparable values in locomotor activity (data not shown).

Acutely injected rimonabant at the dose of $0.1 \mathrm{mg} / \mathrm{kg}$ did not cause any significant change in depression-like behavior in FST studies (Fig. 6B) as the immobility parameters were similar to the vehicle treated animals. This result indicates that rimonabant does not affect the depression like behavior under these conditions. 
A

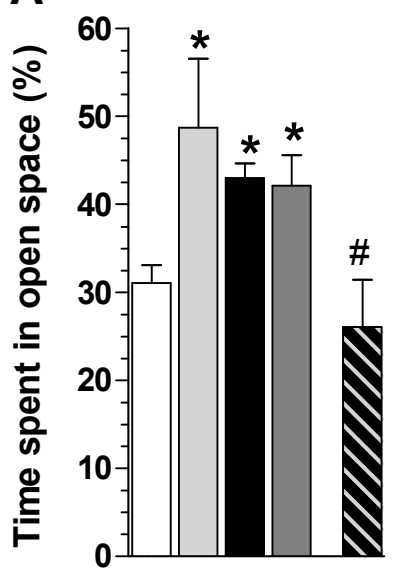

B

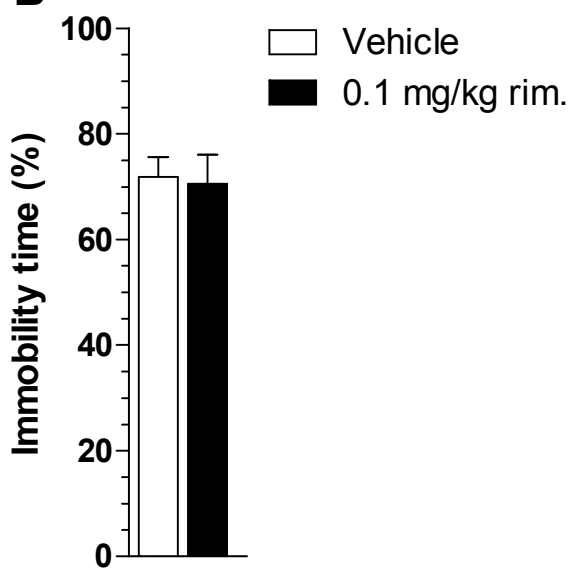

Figure 6 The effect of acute low dose rimonabant treatment on depressive- and anxiety-like behavior in wild type mice. Animal treatments were conducted as described under section 2.3, while EPM and FST behavioral tests were performed as described in section 2.9 and 2.10 respectively. (A) Elevated plus maze test results representing the time spent in open space compared to the total test duration time, which quantifies the anxiety-like behavior of the animals. Combined treatment refers to the coinjection of $1 \mathrm{mg} / \mathrm{kg}$ nor-BNI and $0.1 \mathrm{mg} / \mathrm{kg}$ rimonabant. * indicates the significant enhancement in the values compared to vehicle (One-way ANOVA, Bonferroni's Multiple Comparison post hoc test; $0.1 \mathrm{mg} / \mathrm{kg}$ rim.: $\mathrm{P}<0.01,1 \mathrm{mg} / \mathrm{kg}$ nor-BNI: $\mathrm{P}<0.05$; $1 \mathrm{mg} / \mathrm{kg}$ rim.: $\mathrm{P}<0.05$ ) while \# represents the significant reduction of the combined treatment values compared to $0.1 \mathrm{mg} / \mathrm{kg}$ rimonabant and $1 \mathrm{mg} / \mathrm{kg}$ nor-BNI alone (Oneway ANOVA, Bonferroni's Multiple Comparison post hoc test; $\mathrm{P}<0.01$ ). (B) Forcedswimming test results representing the immobility time in percentage compared to the total test duration time. This type of experiment quantifies the depressive-like behavior of the animals. Columns represent means \pm S.E.M. for at least three experiments performed with at least 8 animals per group in all behavioral tests. 


\section{DISCUSSION}

Since the development of the $\mathrm{CB}_{1}$ receptor antagonist/inverse agonist rimonabant, there have been a growing number of studies describing its non- $\mathrm{CB}_{1}$ related actions (Fong et al., 2009; Le Foll and Goldberg, 2005; Pertwee, 2010). The opioid system is one of the most likely interactional partner of rimonabant (Fong et al., 2009; Kathmann et al., 2006; Le Foll and Goldberg, 2005; Pertwee, 2010), though with evidences mostly related to the MOR system (Cinar and Szücs, 2009; Kathmann et al., 2006; Seely et al., 2012; Zádor et al., 2012). Because the KORs have a major role on mediating anxiety- and depressionlike behavior and rimonabant is also known for inducing mood alterations, our study focused on to better understand the background of the possible connection between these findings. After investigating the direct impact of rimonabant in vitro in CHO-rKOR cell lines and in forebrain membrane preparations, we applied an acute low dose of rimonabant and followed the alterations in KOR signaling and KOR protein expression level in the forebrain, which to the best of our knowledge was never reported before. Finally, but most interestingly we revealed these consequences at the behavioral level. For our studies we used $\mathrm{CHO}-\mathrm{rKOR}$ cells lines and either $\mathrm{CB}_{1}$ single knockout or $\mathrm{CB}_{1} / \mathrm{CB}_{2}$ double knockout mice to better understand the involvement of these receptors in the observed effects.

We first investigated the direct binding affinity of rimonabant to KORs in competition binding experiments in CHO-rKOR membrane fractions. According to these studies, rimonabant directly inhibited KOR radioligand binding, but only in the micromolar concentrations. These findings correspond well with previous reports on other opioid receptors in similar experimental conditions (Cinar and Szücs, 2009; Fong et al., 2009; Kathmann et al., 2006; Seely et al., 2012; Zádor et al., 2012, 2014).

Because rimonabant affected KOR binding in the micromolar range, we examined whether rimonabant can effect KOR mediated G-protein basal activity and KOR activation in similar concentrations. These studies were accomplished in $\left[{ }^{35} \mathrm{~S}\right] \mathrm{GTP} \gamma \mathrm{S}$ binding assays using CHO-rKOR cell membranes. Our results revealed that rimonabant shows both an inverse agonistic as well as an antagonistic character at this level. Rimonabant significantly inhibited KOR mediated G-protein basal activity, indicating an 
inverse agonistic character. This effect was reversed by the KOR antagonist nor-BNI at lower $(0.5$ and $1 \mu \mathrm{M})$ micromolar concentrations, but not at higher micromolar range (10 $\mu \mathrm{M})$, indicating rimonabant's KOR specificity only at lower micromolar range. Therefore $10 \mu \mathrm{M}$ or higher concentration of rimonabant might be considered as unspecific, which correlates with previous reports on MOR and DOR transfected CHO cell lines (Cinar and Szücs, 2009; Seely et al., 2012; Zádor et al., 2014) or with publications showing a non- $\mathrm{CB}_{1}$ receptor related inverse agonistic effect of rimonabant at these concentrations (Breivogel et al., 2001; MacLennan et al., 1998). We have also shown that in dynorphin (1-11)-stimulated G-protein activity measurements performed in CHO-rKOR cell membranes, rimonabant could significantly decrease maximal G-protein activity at 1 $\mu \mathrm{M}$ and $10 \mu \mathrm{M}$ concentrations and the potency of the activator ligand in $10 \mu \mathrm{M}$ concentrations. The inhibitory effect of rimonabant upon KOR activation can be due to either an inverse agonistic or antagonistic character, that might be partially unspecific at a higher, $10 \mu \mathrm{M}$ concentrations. The reduced stimulator ligand potency confirms previous data from U69593-stimulated $\left[{ }^{35} \mathrm{~S}\right] \mathrm{GTP} \gamma \mathrm{S}$ binding experiments performed in CHO-rKOR cell membranes (Walentiny et al., 2010). Additionally, similar results were observed previously by our group in experiments performed with MOR (Zádor et al., 2012) and DOR (Zádor et al., 2014).

In nature, GPCRs are well known to dimerize with each other or with distant families forming homo-, heterodimers or oligomers (Birdsall, 2010; Fonseca and Lambert, 2009; González-Maeso, 2011), moreover they are able to influence other GPCR's activity without having a direct interaction (González-Maeso, 2011; Hamm, 1998; Hur and Kim, 2002; Jordan and Devi, 1999; Selbie and Hill, 1998). The $\mathrm{CB}_{1}$ cannabinoid receptor, which is the main receptor that mediates the effects of rimonabant, is the most widely expressed GPCR in the brain (Herkenham et al., 1991; Howlett et al., 1990) and shows overlapping expression with KOR at the regions of our interest (Hohmann and Herkenham, 2000; Lever, 2007; Mansour et al., 1995; Marsicano and Lutz, 1999; Sim and Childers, 1997; Svízenská et al., 2008). Recently, the $\mathrm{CB}_{2}$ cannabinoid receptor has been also shown to have neuronal expression in different brain regions (Gong et al., 2006; Herkenham et al., 1991; Pertwee and Howlett, 2010; Svízenská et al., 2008; Van Sickle et al., 2005) and it has been reported to interact with 
the opioid receptor system (Páldy et al., 2008; Páldyová et al., 2008). Because these receptors are expressed in the brain, further KORs and $\mathrm{CB}_{1}$ receptors could be either somatodendrically located within a neuron or could be present in the axon terminals (Arvidsson et al., 1995; Thibault et al., 2013), the direct impact on each other's activity should be considered. Therefore, to better understand if the two cannabinoid receptors are involved in the effects of rimonabant on KOR system, we used genetically modified mice lacking either $\mathrm{CB}_{1}$ or both $\mathrm{CB}_{1} / \mathrm{CB}_{2}$ cannabinoid receptors and followed the impact of rimonabant on KOR signaling. Functional $\left[{ }^{35} \mathrm{~S}\right] \mathrm{GTP} \gamma \mathrm{S}$ binding assay revealed that rimonabant at $1 \mu \mathrm{M}$ concentration was able to inhibit dynorphin (1-11)-stimulated $\left[{ }^{35} \mathrm{~S}\right] \mathrm{GTP} \gamma \mathrm{S}$ binding in mouse forebrain membrane preparations. This effect was $\mathrm{CB}_{1}$ and $\mathrm{CB}_{2}$ receptor independent as both the knockouts showed comparable results with their corresponding controls. Similar results were observed by our previous studies regarding to MOR (Zádor et al., 2012) and DOR (Zádor et al., 2014).

Evidences showing a cross-talk between the endocannabinoid and the endogenous opioid system have been widely published (for review see Cota et al., 2006; Manzanares et al., 2005), even at the level of KOR (Gerald et al., 2006; Ghozland et al., 2002; Lockie et al., 2011; Steiner et al., 1999; Urigüen et al., 2005; Walentiny et al., 2010). Rimonabant and the opioid system is known to have a bidirectional interaction as well, for example it can directly interact with MORs and DORs (Cinar and Szücs, 2009; Fong et al., 2009; Kathmann et al., 2006; Seely et al., 2012; Zádor et al., 2014, 2012). Recently, it has been revealed that the $\mu$-opioid system is involved in metabolic effects, whereas the $\kappa$-opioid system affects the mood related properties of rimonabant at higher, repeated administration (Lockie et al., 2011). However, when choosing the right dose of rimonabant for in vivo administration one should be very careful, as upon a chronic and/or high micromolar dose application its non- $\mathrm{CB}_{1}$ mediated effects will probably occur(Le Foll and Goldberg, 2005; Pertwee, 2010). Therefore, for our in vivo studies we choose a lower, and not yet reported dose of $0.1 \mathrm{mg} / \mathrm{kg}$, since so far the vast majority of the demonstrated interactions of rimonabant with the opioid system were described with at least ten times higher dosage (Beyer et al., 2010; De Vries et al., 2003; Le Foll and Goldberg, 2005; Lockie et al., 2011). We used $\mathrm{CB}_{1}$ knockout mice to understand the impact of the $\mathrm{CB}_{1}$ receptors in the observed effects and we first followed the changes in 
KOR signaling and KOR protein expression level $24 \mathrm{~h}$ after rimonabant administration in the forebrain. Similarly to that of seen in the in vitro studies, rimonabant showed an inhibitory effect on dynorphin (1-11)-stimulated KOR G-protein activity in $\left[{ }^{35} \mathrm{~S}\right] \mathrm{GTP} \gamma \mathrm{S}$ binding assays which was yet again comparable in $\mathrm{CB}_{1}$ K.O. and their controls, indicating a $\mathrm{CB}_{1}$ receptor independent action. These results correspond with previously described G-protein activity measurements accomplished on MOR in similar experimental conditions (Zádor et al., 2012). However, it's worth to note that the mechanisms behind the acute in vivo effects of rimonabant on KOR G-protein activity might be entirely different and more complex from that of seen in vitro. One possible explanation could be that the very low dose systematic administration of rimonabant reduces the available KOR receptors in the forebrain; therefore the activator ligand activates fewer receptors in the system. Thus, we have followed the changes of KOR protein expression levels in Western blot studies. We have seen a slight, but significantly decrease of the KOR protein expression which might lead, or at least partially contribute to the observed effects on KOR signaling.

The anxiety modulating effects of rimonabant are well known, though the results on this topic are rather conflicting (Beyer et al., 2010; Lee et al., 2009; Lockie et al., 2011; Navarro et al., 1997; Rodgers et al., 2003). Rimonabant, as an antiobesity drug was withdrawn from the market because of a significant drug-related risk of serious psychiatric disorders including anxiety and depression. The undesirable effects occurred after chronic treatment according to clinical (Christensen et al., 2007; Moreira and Crippa, 2009) and preclinical studies (Beyer et al., 2010). However there are evidences showing that acutely administered low dose $(1-3 \mathrm{mg} / \mathrm{kg})$ of rimonabant can have anxiolytic effects on rodents in EPM studies (Haller et al., 2002; Rodgers et al., 2003, Arévalo et al., 2001,Navarro et al., 1997) and can also reduce depression in FST studies (Tzavara et al., 2003). According to Lee and co-workers $10 \mathrm{mg} / \mathrm{kg}$ per os single rimonabant treatment also reduced immobility in FST studies to the level of imipramine, a standard antidepressant (Lee et al., 2009).

At the same time, there is little known what players might be participating in the psychiatric effects upon acute administration. Stimulated by the observations that the mood related effects of rimonabant are linked to the KOR system (Lockie et al., 2011), 
but trying to avoid the unspecificity of this compound, we have conducted behavior studies to examine the depression-and anxiety-like behavior of wild type mice after the same rimonabant treatment conditions applied in our previous studies. Accordingly 0.1 $\mathrm{mg} / \mathrm{kg}$ rimonabant provoked an anxiolytic effect in EPM studies $24 \mathrm{~h}$ following the i.p. treatment. Similar results were observed by Haller and co-workers (Haller et al., 2002), but with higher dosage $(3 \mathrm{mg} / \mathrm{kg})$. Moreover this effect was inhibited by the KOR antagonist nor-BNI, indicating the KOR specificity of rimonabant in this action.

Rimonabant showed $\mathrm{CB}_{1}$ receptor independent inhibitory actions both in our in vitro and in vivo studies. Importantly the in vitro effects of the compound in micromolar concentrations directly involved the KORs, more likely in an inverse agonistic or antagonistic manner. Similar conclusion can be made according to the EPM studies, since it had anxiolytic effect through KOR and also it is known that KOR antagonists have anxiolytic effects (for review see Carlezon et al., 2009). Additionally, the low dose acute treatment reduced KOR protein expression rate, which may result the diminished KOR mediated G-protein activity after the treatment. However this effect of rimonabant may also be indirect, since GPCRs have very complex signaling systems (Oldham and Hamm, 2008), namely they can cross-regulate each other's signaling pathways, communicate with one and other capable of altering each other's physiological responses(GonzálezMaeso, 2011; Hamm, 1998; Hur and Kim, 2002; Jordan and Devi, 1999; Selbie and Hill, 1998).

Despite of the knowledge that rimonabant shows unspecific properties after high dose or chronic administration, here we report that even an acute, low application leads to a $\mathrm{CB}_{1}$ receptor independent action, namely via effecting the KOR signaling system at different levels. This impact has direct consequences at the behavioral level, but importantly the anxiolytic effect is entirely opposite to that of observed after repeated application. Further, this study goes along with our previous (Zádor et al., 2012; 2014) and other findings (Cinar and Szücs, 2009; Kathmann et al., 2006; Lockie et al., 2011; Seely et al., 2012) about the capability of rimonabant to modulate all the three opioid receptor's function at the signaling level at various concentrations. Thus, the possible players mediating the effect of rimonabant are far more complex than it was originally thought. 


\section{ACKNOWLEDGEMENTS}

This study was supported by from the National Development Agency (NFÜ), Budapest, Hungary; Grant No. CK-78566;TÁMOP-4.2.2A-11/1KONV-2012-0024 and OTKA 108518. The authors would like to thank Dr. Zvi Vogel for providing us the CHOrKOR cell lines and also Erzsébet Kusz for growing the cell cultures for us. We would also want to thank Dr. Andreas Zimmer's laboratory for providing us the $\mathrm{CB}_{1} / \mathrm{CB}_{2}$ double knock-out mice, the Isotope Laboratory of BRC for synthetizing the dynorphin (1-11) ligand and Dr. Ibolya Horváth for allowing us to use the membrane detector device during our Western blot studies. Finally we are also very grateful for the assistance of Zsuzsa Canjavec, Ildikó Némethné, Akócsi Mariann, Dr. Reza Samavati and Petra Bodó. 


\section{REFERENCES}

Arvidsson, U., Riedl, M., Chakrabarti, S., Vulchanova, L., Lee, J.H., Nakano, A.H., Lin, X., Loh, H.H., Law, P.Y., Wessendorf, M.W., 1995. The kappa-opioid receptor is primarily postsynaptic: combined immunohistochemical localization of the receptor and endogenous opioids. Proc Natl Acad Sci U S A 92, 5062-6.

Avidor-Reiss, T., Zippel, R., Levy, R., Saya, D., Ezra, V., Barg, J., Matus-Leibovitch, N., Vogel, Z., 1995. kappa-Opioid receptor-transfected cell lines: modulation of adenylyl cyclase activity following acute and chronic opioid treatments. FEBS Lett $361,70-4$.

Bals-Kubik, R., Ableitner, A., Herz, A., Shippenberg, T.S., 1993. Neuroanatomical sites mediating the motivational effects of opioids as mapped by the conditioned place preference paradigm in rats. J Pharmacol Exp Ther 264, 489-95.

Beckstead, R.M., Domesick, V.B., Nauta, W.J., 1979. Efferent connections of the substantia nigra and ventral tegmental area in the rat. Brain Res 175, 191-217.

Benyhe, S., Farkas, J., Tóth, G., Wollemann, M., 1997. Met5-enkephalin-Arg6-Phe7, an endogenous neuropeptide, binds to multiple opioid and nonopioid sites in rat brain. $\mathrm{J}$ Neurosci Res 48, 249-258.

Berger, B., Rothmaier, A.K., Wedekind, F., Zentner, J., Feuerstein, T.J., Jackisch, R., 2006. Presynaptic opioid receptors on noradrenergic and serotonergic neurons in the human as compared to the rat neocortex. Br J Pharmacol 148, 795-806.

Beyer, C.E., Dwyer, J.M., Piesla, M.J., Platt, B.J., Shen, R., Rahman, Z., Chan, K., Manners, M.T., Samad, T. a, Kennedy, J.D., Bingham, B., Whiteside, G.T., 2010. Depression-like phenotype following chronic CB1 receptor antagonism. Neurobiol Dis 39, 148-55.

Birdsall, N.J.M., 2010. Class A GPCR heterodimers: evidence from binding studies. Trends Pharmacol Sci 31, 499-508.

Breivogel, C.S., Griffin, G., Di Marzo, V., Martin, B.R., 2001. Evidence for a new G protein-coupled cannabinoid receptor in mouse brain. Mol Pharmacol 60, 155-63.

Bruchas, M.R., Land, B.B., Chavkin, C., 2010. The dynorphin/kappa opioid system as a modulator of stress-induced and pro-addictive behaviors. Brain Res 1314, 44-55.

Capasso, R., Borrelli, F., Cascio, M.G., Aviello, G., Huben, K., Zjawiony, J.K., Marini, P., Romano, B., Di Marzo, V., Capasso, F., Izzo, a a, 2008. Inhibitory effect of salvinorin A, from Salvia divinorum, on ileitis-induced hypermotility: cross-talk between kappa-opioid and cannabinoid CB(1) receptors. Br J Pharmacol 155, 681-9. 
Carlezon, W.A., Béguin, C., DiNieri, J.A., Baumann, M.H., Richards, M.R., Todtenkopf, M.S., Rothman, R.B., Ma, Z., Lee, D.Y.-W., Cohen, B.M., 2006. Depressive-like effects of the kappa-opioid receptor agonist salvinorin A on behavior and neurochemistry in rats. J Pharmacol Exp Ther 316, 440-7.

Carlezon, W.A., Béguin, C., Knoll, A.T., Cohen, B.M., 2009. Kappa-opioid ligands in the study and treatment of mood disorders. Pharmacol Ther 123, 334-43.

Castagné, V., Moser, P., Roux, S., Porsolt, R.D., 2011. Rodent models of depression: forced swim and tail suspension behavioral despair tests in rats and mice. Curr Protoc Neurosci Chapter 8, Unit 8.10A.

Christensen, R., Kristensen, P.K., Bartels, E.M., Bliddal, H., Astrup, A., 2007. Efficacy and safety of the weight-loss drug rimonabant: a meta-analysis of randomised trials. Lancet 370, 1706-13.

Cinar, R., Szücs, M., 2009. CB1 receptor-independent actions of SR141716 on G-protein signaling: coapplication with the mu-opioid agonist Tyr-D-Ala-Gly-(NMe)Phe-Glyol unmasks novel, pertussis toxin-insensitive opioid signaling in mu-opioid receptorChinese hamster ovary cells. J Pharmacol Exp Ther 330, 567-74.

Cota, D., Tschöp, M.H., Horvath, T.L., Levine, A.S., 2006. Cannabinoids, opioids and eating behavior: the molecular face of hedonism? Brain Res Rev 51, 85-107.

De Vries, T.J., Homberg, J.R., Binnekade, R., Raasø, H., Schoffelmeer, A.N.M., 2003. Cannabinoid modulation of the reinforcing and motivational properties of heroin and heroin-associated cues in rats. Psychopharmacology (Berl) 168, 164-9.

De Zwaan, M., Mitchell, J.E., 1992. Opiate antagonists and eating behavior in humans: a review. J Clin Pharmacol 32, 1060-72.

Demuth, D.G., Molleman, A., 2006. Cannabinoid signalling. Life Sci 78, 549-63.

Filliol, D., Ghozland, S., Chluba, J., Martin, M., Matthes, H.W., Simonin, F., Befort, K., Gavériaux-Ruff, C., Dierich, a, LeMeur, M., Valverde, O., Maldonado, R., Kieffer, B.L., 2000. Mice deficient for delta- and mu-opioid receptors exhibit opposing alterations of emotional responses. Nat Genet 25, 195-200.

Fong, T.M., Shearman, L.P., Stribling, D.S., Shu, J., Lao, J., Huang, C.R.-R., Xiao, J.C., Shen, C.-P., Tyszkiewicz, J., Strack, A.M., DeMaula, C., Hubert, M.-F., GalijatovicIdrizbegovic, A., Owen, R., Huber, A.C., Lanning, C.L., 2009. Pharmacological efficacy and safety profile of taranabant in preclinical species. Drug Dev Res 70, $349-62$.

Fonseca, J., Lambert, N., 2009. Instability of a class A G protein-coupled receptor oligomer interface. Mol Pharmacol 75, 1296-9. 
Frazer, A., 1997. Pharmacology of antidepressants. J Clin Psychopharmacol 17 Suppl 1, 2S-18S.

Gaszner, B., Kormos, V., Kozicz, T., Hashimoto, H., Reglodi, D., Helyes, Z., 2012. The behavioral phenotype of pituitary adenylate-cyclase activating polypeptide-deficient mice in anxiety and depression tests is accompanied by blunted c-Fos expression in the bed nucleus of the stria terminalis, central projecting Edinger-Westphal nucleu. Neuroscience 202, 283-99.

Gerald, T.M., Ward, G.R., Howlett, A.C., Franklin, S.O., 2006. CB1 knockout mice display significant changes in striatal opioid peptide and $\mathrm{D} 4$ dopamine receptor gene expression. Brain Res 1093, 20-4.

Ghozland, S., Matthes, H.W.D., Simonin, F., Filliol, D., Kieffer, B.L., Maldonado, R., 2002. Motivational effects of cannabinoids are mediated by mu-opioid and kappaopioid receptors. J Neurosci 22, 1146-54.

Gong, J.-P., Onaivi, E.S., Ishiguro, H., Liu, Q.-R., Tagliaferro, P.A., Brusco, A., Uhl, G.R., 2006. Cannabinoid CB2 receptors: immunohistochemical localization in rat brain. Brain Res 1071, 10-23.

González-Maeso, J., 2011. GPCR oligomers in pharmacology and signaling. Mol Brain 4, doi: $10.1186 / 1756-6606-4-20$.

Haller, J., Bakos, N., Szirmay, M., Ledent, C., Freund, T.F., 2002. The effects of genetic and pharmacological blockade of the CB1 cannabinoid receptor on anxiety. Eur J Neurosci 16, 1395-1398.

Haller, V.L., Stevens, D.L., Welch, S.P., 2008. Modulation of opioids via protection of anandamide degradation by fatty acid amide hydrolase. Eur J Pharmacol 600, 50-8.

Hamm, H., 1998. The many faces of G protein signaling. J Biol Chem 273, 669-72.

Herkenham, M., Lynn, A.B., Johnson, M.R., Melvin, L.S., de Costa, B.R., Rice, K.C., 1991. Characterization and localization of cannabinoid receptors in rat brain: a quantitative in vitro autoradiographic study. J Neurosci 11, 563-83.

Hohmann, A.G., Herkenham, M., 2000. Localization of cannabinoid CB(1) receptor mRNA in neuronal subpopulations of rat striatum: a double-label in situ hybridization study. Synapse 37, 71-80.

Howlett, A.C., Bidaut-Russell, M., Devane, W.A., Melvin, L.S., Johnson, M.R., Herkenham, M., 1990. The cannabinoid receptor: biochemical, anatomical and behavioral characterization. Trends Neurosci 13, 420-3. 
Hur, E.M., Kim, K.T., 2002. G protein-coupled receptor signalling and cross-talk: achieving rapidity and specificity. Cell Signal 14, 397-405.

Hurd, Y.L., 1996. Differential messenger RNA expression of prodynorphin and proenkephalin in the human brain. Neuroscience 72, 767-83.

Járai, Z., Wagner, J.A., Varga, K., Lake, K.D., Compton, D.R., Martin, B.R., Zimmer, a M., Bonner, T.I., Buckley, N.E., Mezey, E., Razdan, R.K., Zimmer, A., Kunos, G., 1999. Cannabinoid-induced mesenteric vasodilation through an endothelial site distinct from CB1 or CB2 receptors. Proc Natl Acad Sci U S A 96, 14136-41.

Jordan, B., Devi, L., 1999. G-protein-coupled receptor heterodimerization modulates receptor function. Nature 399, 697-700.

Kathmann, M., Flau, K., Redmer, A., Tränkle, C., Schlicker, E., 2006. Cannabidiol is an allosteric modulator at mu- and delta-opioid receptors. Naunyn Schmiedebergs Arch Pharmacol 372, 354-61.

Knoll, A.T., Meloni, E.G., Thomas, J.B., Carroll, F.I., Carlezon, W.A., 2007. Anxiolyticlike effects of kappa-opioid receptor antagonists in models of unlearned and learned fear in rats. J Pharmacol Exp Ther 323, 838-45.

Le Foll, B., Goldberg, S.R., 2005. Cannabinoid CB 1 Receptor Antagonists as Promising New Medications for Drug Dependence. J Pharmacol Exp Ther 312, 875-83.

Ledent, C., Valverde, O., Cossu, G., Petitet, F., Aubert, J.F., Beslot, F., Böhme, G.A., Imperato, A., Pedrazzini, T., Roques, B.P., Vassart, G., Fratta, W., Parmentier, M., 1999. Unresponsiveness to cannabinoids and reduced addictive effects of opiates in CB1 receptor knockout mice. Science 283, 401-4.

Lee, S., Kim, D.H., Yoon, S.-H., Ryu, J.H., 2009. Sub-chronic administration of rimonabant causes loss of antidepressive activity and decreases doublecortin immunoreactivity in the mouse hippocampus. Neurosci Lett 467, 111-6.

Lénárt, N., Szegedi, V., Juhász, G., Kasztner, A., Horváth, J., Bereczki, E., Tóth, M.E., Penke, B., Sántha, M., 2012. Increased tau phosphorylation and impaired presynaptic function in hypertriglyceridemic ApoB-100 transgenic mice. PLoS One 7, e46007.

Lever, J.R., 2007. PET and SPECT imaging of the opioid system : receptors, radioligands and avenues for drug discovery and development. Curr Pharm Des 13, 33-49.

Lockie, S.H., Czyzyk, T.A., Chaudhary, N., Perez-Tilve, D., Woods, S.C., Oldfield, B.J., Statnick, M.A., Tschöp, M.H., 2011. CNS opioid signaling separates cannabinoid receptor 1-mediated effects on body weight and mood-related behavior in mice. Endocrinology 152, 3661-7. 
MacLennan, S.J., Reynen, P.H., Kwan, J., Bonhaus, D.W., 1998. Evidence for inverse agonism of SR141716A at human recombinant cannabinoid CB1 and CB2 receptors. Br J Pharmacol 124, 619-22.

Mague, S.D., Pliakas, A.M., Todtenkopf, M.S., Tomasiewicz, H.C., Zhang, Y., Stevens, W.C., Jones, R.M., Portoghese, P.S., Carlezon, W.A., 2003. Antidepressant-like effects of kappa-opioid receptor antagonists in the forced swim test in rats. J Pharmacol Exp Ther 305, 323-30.

Mansour, A., Fox, C., Akil, H., Watson, S., 1995. Opioid-receptor mRNA expression in the rat CNS: anatomical and functional implications. Trends Neurosci 18, $22-9$.

Manzanares, J., Ortiz, S., Oliva, J.M., Pérez-Rial, S., Palomo, T., 2005. Interactions between cannabinoid and opioid receptor systems in the mediation of ethanol effects. Alcohol Alcohol 40, 25-34.

Marsicano, G., Lutz, B., 1999. Expression of the cannabinoid receptor CB1 in distinct neuronal subpopulations in the adult mouse forebrain. Eur J Neurosci 11, 42134225 .

McLaughlin, J.P., Marton-Popovici, M., Chavkin, C., 2003. Kappa opioid receptor antagonism and prodynorphin gene disruption block stress-induced behavioral responses. J Neurosci 23, 5674-83.

Millan, M.J., 2004. The role of monoamines in the actions of established and "novel" antidepressant agents: a critical review. Eur J Pharmacol 500, 371-84.

Moreira, F.A., Crippa, J.A.S., 2009. The psychiatric side-effects of rimonabant Os efeitos-colaterais psiquiátricos do rimonabanto $31,145-153$.

Navarro, M., Hernández, E., Muñoz, R.M., del Arco, I., Villanúa, M. a, Carrera, M.R., Rodríguez de Fonseca, F., 1997. Acute administration of the CB1 cannabinoid receptor antagonist SR 141716A induces anxiety-like responses in the rat. Neuroreport 8, 491-6.

Newton, S.S., Thome, J., Wallace, T.L., Shirayama, Y., Schlesinger, L., Sakai, N., Chen, J., Neve, R., Nestler, E.J., Duman, R.S., 2002. Inhibition of cAMP response element-binding protein or dynorphin in the nucleus accumbens produces an antidepressant-like effect. J Neurosci 22, 10883-90.

Oldham, W.M., Hamm, H.E., 2008. Heterotrimeric G protein activation by G-proteincoupled receptors. Nat Rev Mol Cell Biol 9, 60-71.

Padwal, R.S., Majumdar, S.R., 2007. Drug treatments for obesity: orlistat, sibutramine, and rimonabant. Lancet 369, 71-7. 
Páldy, E., Bereczki, E., Sántha, M., Wenger, T., Borsodi, A., Zimmer, A., Benyhe, S., 2008. CB(2) cannabinoid receptor antagonist SR144528 decreases mu-opioid receptor expression and activation in mouse brainstem: role of $\mathrm{CB}(2)$ receptor in pain. Neurochem Int 53, 309-16.

Páldyová, E., Bereczki, E., Sántha, M., Wenger, T., Borsodi, A., Benyhe, S., 2008. Noladin ether, a putative endocannabinoid, inhibits mu-opioid receptor activation via CB2 cannabinoid receptors. Neurochem Int 52, 321-8.

Pertwee, R.G., 2010. Receptors and channels targeted by synthetic cannabinoid receptor agonists and antagonists. Curr Med Chem 17, 1360-81.

Pertwee, R.G., Howlett, A.C., 2010. International Union of Basic and Clinical Pharmacology. LXXIX. Cannabinoid receptors and their ligands: beyond CB1 and CB2. Pharmacol Rev 62, 588-631.

Pfeiffer, A., Brantl, V., Herz, A., Emrich, H.M., 1986. Psychotomimesis mediated by kappa opiate receptors. Science 233, 774-6.

Rinaldi-Carmona, M., Barth, F., Héaulme, M., Shire, D., Calandra, B., Congy, C., Martinez, S., Maruani, J., Néliat, G., Caput, D., 1994. SR141716A, a potent and selective antagonist of the brain cannabinoid receptor. FEBS Lett 350, 240-4.

Rodgers, R.J., Haller, J., Halasz, J., Mikics, E., 2003. “One-trial sensitization” to the anxiolytic-like effects of cannabinoid receptor antagonist SR141716A in the mouse elevated plus-maze. Eur J Neurosci 17, 1279-1286.

Schwarzer, C., 2009. 30 years of dynorphins--new insights on their functions in neuropsychiatric diseases. Pharmacol Ther 123, 353-70.

Seely, K. a, Brents, L.K., Franks, L.N., Rajasekaran, M., Zimmerman, S.M., Fantegrossi, W.E., Prather, P.L., 2012. AM-251 and rimonabant act as direct antagonists at muopioid receptors: implications for opioid/cannabinoid interaction studies. Neuropharmacology 63, 905-15.

Selbie, L.A., Hill, S.J., 1998. G protein-coupled- receptor cross-talk : the fine-tuning of multiple pathways. Trends Pharmacol Sci 19, 87-93.

Shippenberg, T.S., LeFevour, A., Chefer, V.I., 2008. Targeting endogenous mu- and delta-opioid receptor systems for the treatment of drug addiction. CNS Neurol Disord Drug Targets 7, 442-53.

Sim, L.J., Childers, S.R., 1997. Anatomical distribution of mu, delta, and kappa opioidand nociceptin/orphanin FQ-stimulated [35S] guanylyl-5'-O-(gamma-thio)triphosphate binding in guinea pig brain. J Comp Neurol 386, 562-72. 
Sim, L.J., Selley, D.E., Childers, S.R., 1995. In vitro autoradiography of receptoractivated $\mathrm{G}$ proteins in rat brain by agonist-stimulated guanylyl 5'-[gamma[35S]thio]-triphosphate binding. Proc Natl Acad Sci USA 92, 7242-46.

Simon, H., Le Moal, M., Calas, A., 1979. Efferents and afferents of the ventral tegmental-A10 region studied after local injection of $[3 \mathrm{H}]$ leucine and horseradish peroxidase. Brain Res 178, 17-40.

Smith, P.B., Welch, S.P., Martin, B.R., 1994. Interactions between delta 9tetrahydrocannabinol and kappa opioids in mice. J Pharmacol Exp Ther 268, 13817.

Steiner, H., Bonner, T.I., Zimmer, A.M., Kitai, S.T., Zimmer, A., 1999. Altered gene expression in striatal projection neurons in $\mathrm{CB} 1$ cannabinoid receptor knockout mice. Proc Natl Acad Sci U S A 96, 5786-90.

Svízenská, I., Dubový, P., Sulcová, A., 2008. Cannabinoid receptors 1 and 2 (CB1 and $\mathrm{CB} 2$ ), their distribution, ligands and functional involvement in nervous system structures - a short review. Pharmacol Biochem Behav 90, 501-11.

Tanaka, M., Yoshida, M., Emoto, H., Ishii, H., 2000. Noradrenaline systems in the hypothalamus, amygdala and locus coeruleus are involved in the provocation of anxiety: basic studies. Eur J Pharmacol 405, 397-406.

Thibault, K., Carrel, D., Bonnard, D., Gallatz, K., Simon, A., Biard, M., Pezet, S., Palkovits, M., Lenkei, Z., 2013. Activation-dependent subcellular distribution patterns of CB1 cannabinoid receptors in the rat forebrain. Cereb Cortex 23, 258191.

Traynor, R., Nahorski, R., Traynor, J.R., Nahorski, S.R., 1995. Modulation by mu-opioid agonists of guanosine-5'-O-(3-[35S]thio)triphosphate binding to membranes from human neuroblastoma SH-SY5Y cells. Mol Pharmacol 47, 848-54.

Tzavara, E.T., Davis, R.J., Perry, K.W., Li, X., Salhoff, C., Bymaster, F.P., Witkin, J.M., Nomikos, G.G., 2003. The CB1 receptor antagonist SR141716A selectively increases monoaminergic neurotransmission in the medial prefrontal cortex: implications for therapeutic actions. Br J Pharmacol 138, 544-53.

Urigüen, L., Berrendero, F., Ledent, C., Maldonado, R., Manzanares, J., 2005. Kappaand delta-opioid receptor functional activities are increased in the caudate putamen of cannabinoid CB1 receptor knockout mice. Eur J Neurosci 22, 2106-10.

Van Sickle, M.D., Duncan, M., Kingsley, P.J., Mouihate, A., Urbani, P., Mackie, K., Stella, N., Makriyannis, A., Piomelli, D., Davison, J.S., Marnett, L.J., Di Marzo, V., Pittman, Q.J., Patel, K.D., Sharkey, K. a, 2005. Identification and functional characterization of brainstem cannabinoid CB2 receptors. Science. 
Wadenberg, M.-L.G., 2003. A review of the properties of spiradoline: a potent and selective kappa-opioid receptor agonist. CNS Drug Rev 9, 187-98.

Walentiny, D., Vann, R., Warner, J., 2010. Kappa opioid mediation of cannabinoid effects of the potent hallucinogen, salvinorin A, in rodents. Psychopharmacology (Berl) 210, 275-84.

Walf, A.A., Frye, C.A., 2007. The use of the elevated plus maze as an assay of anxietyrelated behavior in rodents. Nat Protoc 2, 322-8.

Wittmann, W., Schunk, E., Rosskothen, I., Gaburro, S., Singewald, N., Herzog, H., Schwarzer, C., 2009. Prodynorphin-derived peptides are critical modulators of anxiety and regulate neurochemistry and corticosterone. Neuropsychopharmacology $34,775-85$.

Yeomans, M.R., Gray, R.W., 1997. Effects of naltrexone on food intake and changes in subjective appetite during eating: evidence for opioid involvement in the appetizer effect. Physiol Behav 62, 15-21.

Zádor, F., Kocsis, D., Borsodi, A., Benyhe, S., 2014. Micromolar concentrations of rimonabant directly inhibits delta opioid receptor specific ligand binding and agonist-induced G-protein activity. Neurochem Int 67, 14-22.

Zádor, F., Ötvös, F., Benyhe, S., Zimmer, A., Páldy, E., 2012. Inhibition of forebrain $\mu-$ opioid receptor signaling by low concentrations of rimonabant does not require cannabinoid receptors and directly involves $\mu$-opioid receptors. Neurochem Int 61 , $378-88$. 